\title{
Geobody architecture of continental carbonates: "Gazda" travertine quarry (Süttő, Gerecse Hills, Hungary)
}

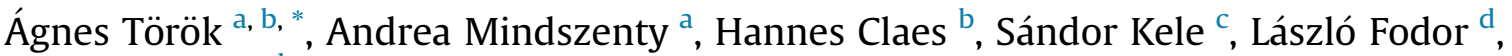 \\ Rudy Swennen ${ }^{b}$ \\ a Institute of Geography and Earth Sciences, Department of Physical and Applied Geology, Eötvös Loránd University, Pázmány P. Sétány 1/c, 1117 Budapest, \\ Hungary \\ ${ }^{\mathrm{b}}$ Department of Earth and Environmental Sciences, KU Leuven, Leuven, Celestijnenlaan 200E, 3001 Heverlee, Belgium \\ c Institute for Geological and Geochemical Research, Research Centre for Astronomy and Earth Sciences, Hungarian Academy of Sciences, Budaörsi út 45, \\ 1112 Budapest, Hungary \\ d MTA-ELTE Geological, Geophysical and Space Science Research Group, Pázmány P. Sétány 1/c, 1117 Budapest, Hungary
}

\section{A R T I C L E I N F O}

\section{Article history:}

Received 29 February 2016

Received in revised form

22 August 2016

Accepted 13 September 2016

Available online $\mathrm{xxx}$

\section{Keywords:}

Travertine

Paleoenvironmental reconstruction

Diagenesis

Stable isotopes

Tectonics

\begin{abstract}
A B S T R A C T
The Gazda quarry is one of the largest outcrops of the present-day Süttö travertine complex that is situated close to the town of Süttő (Hungary), in the Pannonian Basin. Sedimentological and petrographical analyses show that the Gazda travertine body is built out of phytohermal, wavy laminated, massive and flat laminated travertine lithofacies representing reed mound, slope, lacustrine and palustrine depositional environments, respectively. Based on petrographic analyses, the following three main textural features were recognized that allow to describe the most common microscopic features: (1) micrite textures; (2) micritic coatings and crusts; and (3) different types of clasts. Each major lithofacies is characterized by a particular association of these textural types.

The geometry of the travertine beds follows the antecedent land-surface, a NE-SW striking prePleistocene valley. It is proposed that in this valley travertine precipitation took place along a gently sloping terrain. The Gazda travertine system was fed by at least two groundwater-springs. One of them was located NE of the quarry from which waters were flowing along the axis of the valley. The other source was located to the East of the Gazda quarry and waters joined the main water-course along the valley. Closest to the confluence, a phytohermal mound developed with lateral slope and eventual pond depositional systems. Onlapping and interfingering with the flat laminated lithofacies indicate alternating activity of the two springs. Fractures observed in the quarry are mainly related to postdepositional gravitational sliding, however, neotectonic forces resulting in NW-SE tension also played a role in the formation of the fractures.

Stable oxygen and carbon isotope analyses show that water temperature was approximately $25{ }^{\circ} \mathrm{C}$. Petrographic studies indicate that only syn-diagenetic processes affected the precipitates. Therefore the original stable oxygen isotope signatures, characteristic of the depositional environment, were preserved.

Detailed sedimentological and geochemical study of the Gazda travertine complex allowed small-scale facies characterization providing information about the ancient depositional environment and the heterogeneous nature of these carbonates.
\end{abstract}

() 2016 Elsevier Ltd and INQUA. All rights reserved.

\footnotetext{
* Corresponding author. Institute of Geography and Earth Sciences, Department of Physical and Applied Geology, Eötvös Loránd University, Pázmány P. Sétány 1/c, 1117 Budapest, Hungary
}

E-mail address: agi.torok@kuleuven.be (Á. Török).

\section{Introduction}

Over the past years, interest in continental carbonates has significantly increased. The reason for the special attention are major hydrocarbon discoveries in lacustrine basins of the South Atlantic rift-sag on the Sao Paulo Plateau (Wright, 2012) and also offshore Angola (Greenhalgh et al., 2011; Saller et al., 2016). The 
major reservoirs in these areas turned out to be microbialites (Gomes et al., 2012) situated at a depth of $5 \mathrm{~km}$, below $\sim 2 \mathrm{~km}$ of salt and $\sim 2 \mathrm{~km}$ of water depth. The information available about these areas is highly limited because only few cores were taken from the exploration wells and industrial data remain confidential. The microbialite reservoir rocks, however, show significant similarities with continental carbonate deposits (travertine and tufa), particularly in terms of the microbial influence on their formation (Gomes et al., 2012). Exposed freshwater limestones potentially can serve as field analogues for the Brazilian and Angolan reservoirs. Several case studies were recently published providing information about depositional settings (Ronchi and Francesco, 2015; Claes et al., $2015,2016)$ and petrophysical properties of these freshwater limestones (e.g. Soete et al., 2015). The challenges in understanding the formation and the heterogeneous nature of these carbonates and their impact on porosity and permeability emphasize the necessity for analogue sediment-petrological studies.

Detailed investigation of tufas and travertines started in the last century. These strata belong to the group of continental carbonates which precipitated from $\mathrm{CaCO}_{3}$-rich waters either at ambient or at higher temperatures. Carbonate precipitation takes place when fluids become oversaturated with regard to $\mathrm{CaCO}_{3}$ (which may happen due to $\mathrm{CO}_{2}$ degassing, temperature-increase, biological activity, etc.) (Pentecost, 2005; Pedley, 2014). Tufa and travertine deposits represent the two end-members of a continuum where predominant physical-chemical processes control travertine formation whereas tufa formation is controlled mainly by biological processes (Chafetz and Folk, 1984; Golubic et al., 1993; Violante et al., 1994). In some cases, these two end-member lithologies cannot be clearly separated from each other (Pentecost, 2005; Capezzuoli et al., 2014).

According to Pentecost (2005) who left out the term tufa from his classification, two main groups of travertines should be distinguished based on the source of $\mathrm{CO}_{2}$. In case of meteogene travertines, $\mathrm{CO}_{2}$ originates predominantly from the soil-zone (terrestrial vegetation) and the atmosphere (Pentecost and Viles, 1994). Their stable carbon isotope signature is characterized by signatures often varying around $-10 \%$ (V-PDB). On the contrary, the bulk of $\mathrm{CO}_{2}$ in case of thermogene travertines principally comes from deep seated thermal processes. Their stable carbon isotope composition is heavier than that of meteogene travertines, with reported values varying between -3 and $+8 \%$, which is the result of higher rates of degassing as well as possible origin of carbon isotopes from thermometamorphic reactions (Pentecost, 2005). In this study, the term travertine is used as defined by Pentecost (2005).

Depositional facies of continental carbonates are determined by a number of factors. One of the most important is topography. Several authors clearly demonstrated the variation of facies away from the spring orifice. However, likely due to the extreme variability of facies, no standard geomorphologic classification has been proposed. The Hungarian attempts to propose a geomorphological classification were summarized by Scheuer and Schweitzer $(1985,1988)$ and Scheuer (1996) whereas an internationally widely accepted classification was recently proposed by Pentecost (2005).

Numerous Pleistocene travertine outcrops are situated in the northern part of Hungary, especially near the town of Süttő where the travertine bodies are exposed in several active (such as Újharaszt and Gazda) and inactive quarries (like Óharaszt, Diósvölgy and Hegyhát) (Fig. 1). This travertine complex has been investigated by several researchers since the early '50ies (Schréter, 1951; Kele, 2009; Sierralta et al., 2010; Pazonyi, 2014; Pazonyi et al., 2014). Scheuer and Schweitzer (1988) proposed that spring activity was initiated by Early Pleistocene structural movements and that the original centre of spring discharge could have been situated in the
Haraszt Hills (Fig. 1). They furthermore suggested that as a result of tectonic reactivation, the discharge point shifted several times. From sedimentological and petrographical point of view, the travertine complex was studied in detail by Korpás (2003) and Bakacsi and Mindszenty (2004). Based on the investigation of the Hegyhát quarry, Bakacsi and Mindszenty (2004) argued that the depositional environment corresponds to a hydrologically open, relatively high temperature lake with large amounts of biologically induced precipitation (Fig. 1). According to these authors the reasons for the recorded water-level fluctuations might relate to: (1) climatically induced changes in discharge or (2) sudden outflow of water from the pond across broken tufa dams. On the basis of the investigations of Kele (2009) and Sierralta et al. (2010) the Hegyhát travertine formed in Mid Pleistocene times (around $235 \pm 21$ to $31 \pm 45 \mathrm{ka}$ ) whereas the Új-Haraszt travertine is somewhat older (296 $\pm 22 \mathrm{ka})$ and the Diósvölgy travertine is as old as $422 \pm 21 \mathrm{ka} \mathrm{(Fig.} \mathrm{1).}$

This study was carried out in the Gazda quarry which is currently one of the largest outcrops of the Süttö travertine complex. Major aims of this study were (1) to unravel the depositional environment, (2) to reconstruct the geobody architecture with the spatial distribution and changes of individual facies through time and space, (3) to assess the diagenetic overprint and its effect on reservoir properties, and (4) to evaluate the significance of fault and fractures.

\section{Geological setting}

The town of Süttő is located on the right bank of the River Danube in the Pannonian Basin, about $60 \mathrm{~km}$ northwest of Budapest, close to the northern frontier of Hungary (Fig. 1). In the southern neighbourhood of Süttő, in the Gerecse Hills, there are several travertine occurrences that have been quarried since Roman times. The Gerecse Hills are bordered to the North by the Danube valley, to the West by the Dunaalmás-Tata fault, to the South by the Zsámbék Basin and to the East by the Dorog Basin. They are situated in the north-eastern corner of the Transdanubian Range Unit (Fig. 2).

Present-day geological features of Hungary as well as the whole Pannonian region are determined mainly by the Late Cenozoic evolution, evidenced for example by the development of large sedimentary basins. Due to extension-related attenuation of the lithosphere in late Early to Late Miocene times (Royden and Horváth, 1988), the Pannonian Basin is even today characterized by a thin crust $(25-28 \mathrm{~km})$, high geothermal gradient $\left(5^{\circ} \mathrm{C} / 100 \mathrm{~m}\right)$ and elevated heat flow (60-100 $\mathrm{mW} / \mathrm{m}^{2}$ ) (Dövényi and Horváth, 1988; Dövényi et al., 2002). The basin fill consists of one to six kilometre thick series of lacustrine, deltaic and fluviatile clastic sediments of Late Miocene-Pliocene age. They are overlain by Quaternary loess, wind-blown sands and alluvial deposits, covering usually the surface of the plains right below the actual soil. The basins are separated by hilly ranges (uplifted blocks), made up predominantly of Paleozoic, Mesozoic and Paleogene sedimentary sequences and Cenozoic igneous/volcanic rocks.

The Transdanubian Range (TR), striking for $250 \mathrm{~km}$ in NE-SW direction, consists of hills and low mountains, of variegated geology. Significant parts of the TR consist mainly of Triassic carbonates. However, Jurassic, Cretaceous and Paleogene formations also occur in the central zone of the large synform. Together, they determine the basic structural pattern of the TR and form an essentially contiguous huge karstic groundwater reservoir (Haas, 2001; MádlSzőnyi and Tóth, 2015).

From the early Miocene on, the Pannonian Basin was subject to extensional deformation behind the Carpathian subduction zone (Horváth, 1993; Fodor et al., 1999). Thermal subsidence started in the Late Miocene. In the latest Miocene to Pliocene it was followed 


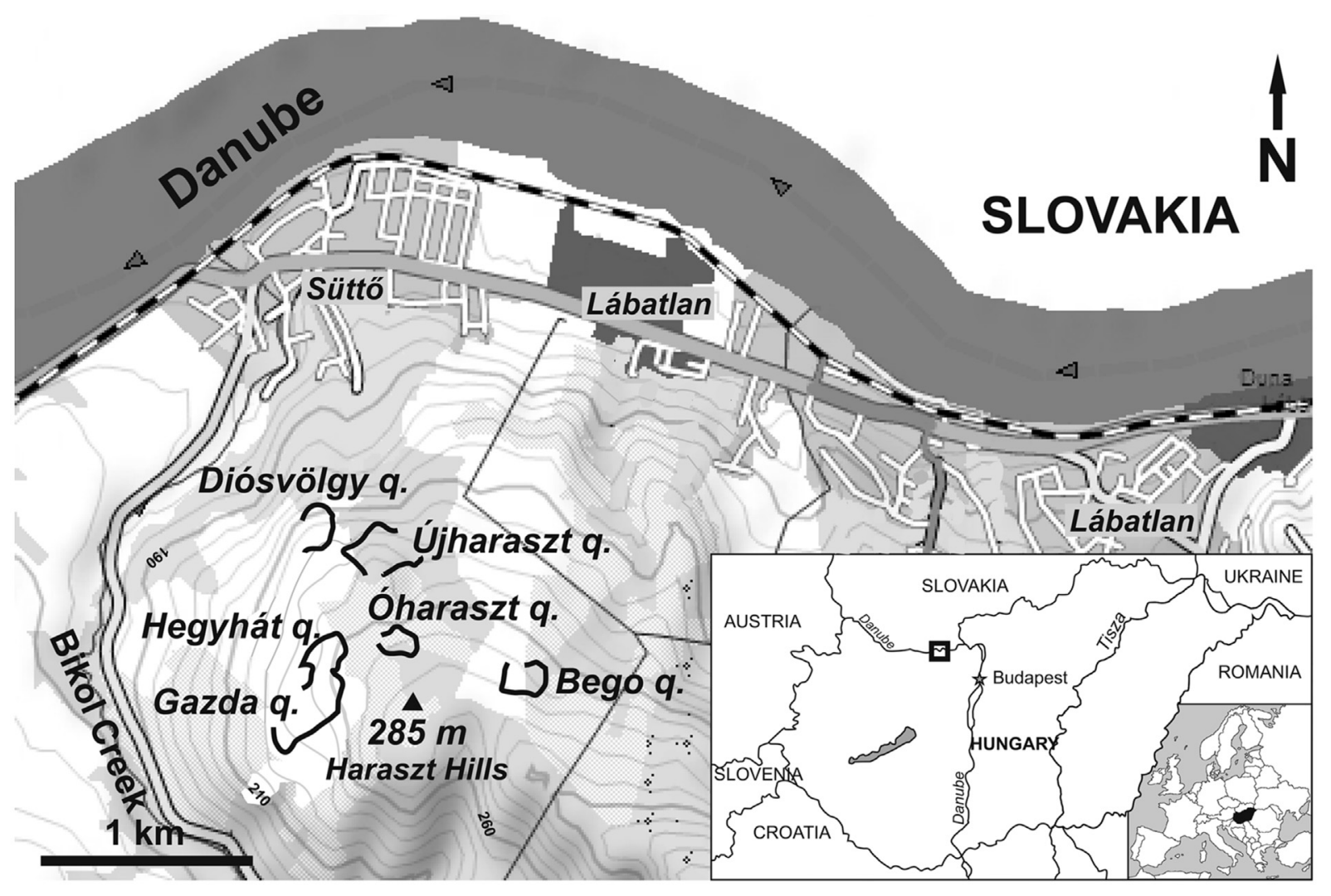

Fig. 1. Topographic map of the Süttő area with indication of the quarries of the Süttő travertine complex.

by structural inversion as a result of continued oblique convergence of the Adriatic plate and the Bohemian Massif. This compression resulted in folding, uplift and subsidence of certain sectors of the basin (Horváth and Cloetingh, 1996; Bada, 1999). The observed terrace horizons along the Danube valley testify of this late uplift of the TR. The terraces are joint products of river incision and uplift of the TR (Pécsi, 1959). The present morphology of the TR is entirely the result of uplift and concomitant denudation related to the Latest Miocene to Recent inversion of the Pannonian Basin (Horváth, 1995). Compression still prevails in most of the basin. Only some sectors of the lowlands are currently subsiding (e.g. the Makó Trough).

Along the Danube valley there are several ancient and recent travertine outcrops such as the Süttö travertine complex in the Gerecse Hills. They formed at the level of the Danube and its tributaries, i.e. the local base level of erosion (Scheuer and Schweitzer, 1988; Ruszkiczay-Rüdiger et al., 2005), but now occur well above the actual valley bottom. The Süttö travertine complex is presently situated at an elevation of 100-120 m above the level of the river on top of a hill where carbonate deposited on top of Late Miocene (Pannonian) to Pliocene gravel, sand and clay deposits. This complex was identified as one of the terrace levels of the Danube by Pécsi et al. (1984). According to Uranium series datings of Kele (2009) and Sierralta et al. (2010) the travertine complex formed in the Middle Pleistocene (412-240 ka). Travertine deposition was followed by erosion and subsequently by deposition of Late Pleistocene loess and Holocene soil (Rolf et al., 2014). Since these travertine occurrences are among the hardest formations of the area (Fig. 2) they are resistant to physical weathering, therefore largescale denudation of this rocky complex is rather unlikely. The Gazda quarry forms the southernmost outcrop of the Süttő travertine deposit situated on the slope of the Haraszt Hill at an altitude of 230-250 $\mathrm{m}$ (a.s.l.) (Fig. 1). All the other known outcrops occur at elevations lower than the top of Haraszt Hill. The quarry is approximately $300 \mathrm{~m}$ long, and it occupies an area of about $5800 \mathrm{~m}^{2}$. Up to now, active quarrying resulted in five excavation levels, each ca. 5-7 m high.

\section{Methods}

\subsection{Petrography}

Macroscopic description was carried out on quarry walls, cores, rock slabs and hand specimens. The aim of the petrographic study was the characterization of the macro- and microfacies focussing on the sedimentary rock constituents, the existing porosity features and the recognition of diagenetic overprint. For this purpose representative samples were selected from each lithofacies. In addition, individual samples were taken from lithotypes showing particular features (e.g. cemented lithologies).

In the course of thin section preparation, samples were resinimpregnated two times. Half of the sample set was impregnated with a blue resin whereas the other half was treated with a fluorescent resin. The microscopic study was carried out with Leica DM LP and Olympus BH-2 microscopes. With regard to fluorescence microscopy a Leica DM LP equipped with a fluorescence lamp (12/ 100 W, type: 301-391.010 with BP450-490/LP515 filter set) was used. For discrimination of the origin of the emitted light which may originate either from organic matter, or from the resin itself, a Zeiss Axioskop 40 fluorescence microscope was used with various filter sets.

Cathodoluminescence microscopy allows to address diagenetic alteration and was executed on a Nikon Optiphot non-polarizing microscope with a modified Technosyn cathodoluminescence 


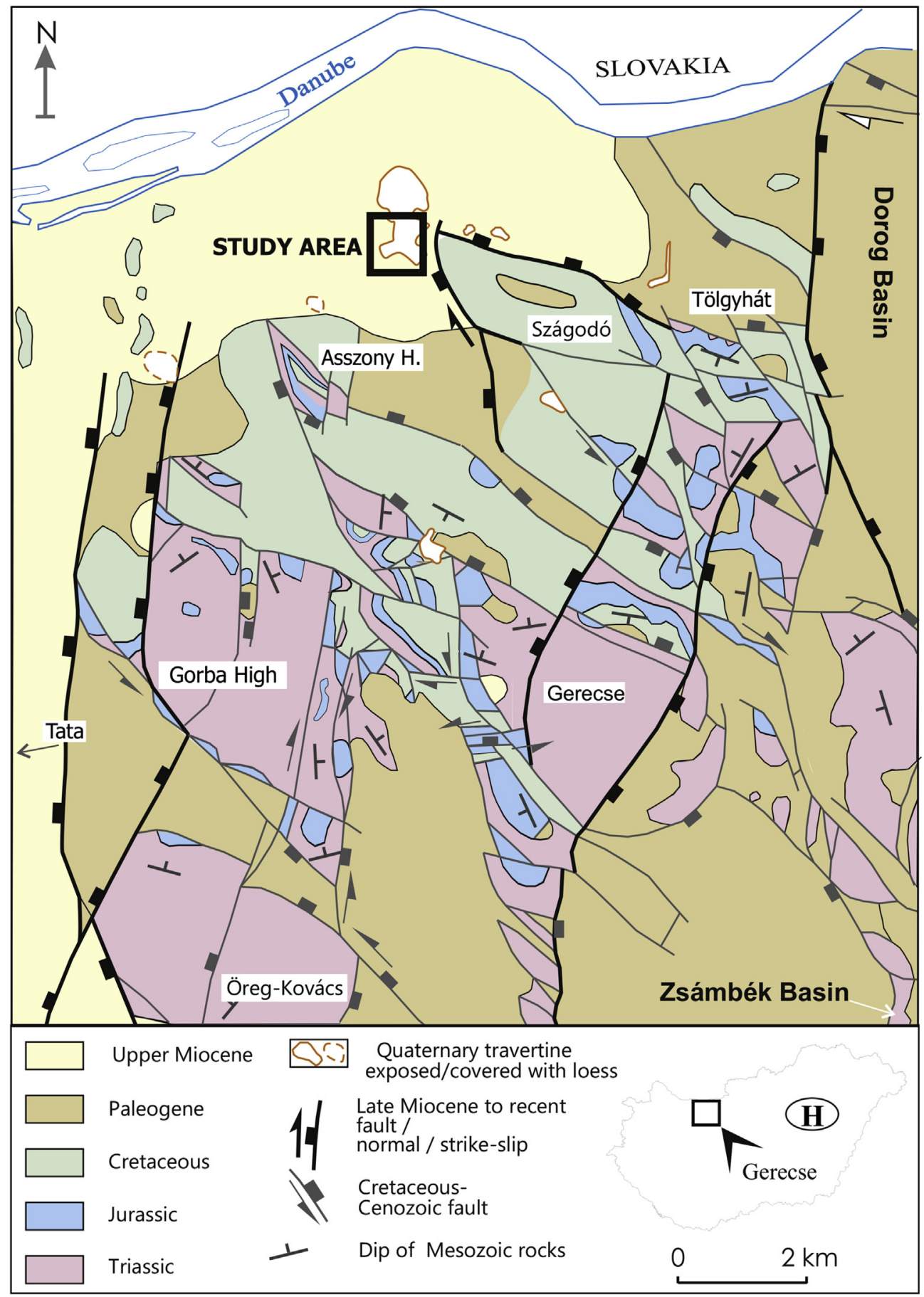

Fig. 2. Pre-Quaternary map of the Gerecse Hills with Quaternary travertine occurrences, modified after Fodor et al. (2013).

stage (model 8200 Mark II) and a Nikon Eclipse Ci-s polarizing microscope with CITL stage.

For petrographic description of freshwater carbonates, most researchers use the classical carbonate terminology. Specific textural classifications only sporadically were proposed (e.g. D'Argenio and Ferreri, 1987). In this study, a combination of Folk's (1959) and Dunham's (1962) classifications were used for the description of travertine fabrics with the term phytohermal taken over from D'Argenio and Ferreri (1987) whereas in order to describe also pore types, the Choquette and Pray (1970) porosity classification was used.

\subsection{Stable oxygen and carbon isotopes}

Twenty four samples were micro-sampled from cores/rock slabs for stable oxygen and carbon isotope analyses which were carried out at "Friedrich-Alexander-Universität" (Erlangen-Nürnberg, Germany). Carbonate powders were reacted with $103 \%$ phosphoric acid at $70{ }^{\circ} \mathrm{C}$ using a Gasbench II connected to a ThermoFinnigan Five Plus mass spectrometer. All values were reported in per mil relative to $\mathrm{V}$-PDB by assigning $\delta^{13} \mathrm{C}$ and $\delta^{18} \mathrm{O}$ values $+1.95 \%$ and $-2.20 \%$ to NBS19 and $-46.6 \%$ and $-26.7 \%$ to LSVEC, respectively. Reproducibility and accuracy was monitored by 
replicate analysis of laboratory standards calibrated to NBS19 and LSVEC. Reproducibility is better than $0.05 \%$ for both carbon and oxygen isotope ratios.

\section{Results}

\subsection{Description of macroscopic lithofacies}

Based on macroscopic observations, the following four lithofacies were distinguished (Fig. 5).

\subsubsection{Phytohermal travertine lithofacies}

Macroscopically, the predominant lithofacies is made up of massive brownish travertine. Within this lithofacies, slight lamination can also be observed that is visualized by brown and black mottling (Fig. 3A). The thickness of laminae ranges between 3 and $10 \mathrm{~cm}$. However, the thickness is strongly variable, changing even along one and the same lamina. Phytohermal travertine is characterized by cement-reduced reed and other macrophyte moulds as well as a highly irregular shaped framework porosity (Fig. 3B). The size of the pores ranges between 1 and $10 \mathrm{~cm}$. Bio-moulds appear both "in situ" as vertically oriented rod-shaped pores or they can result from allochthonous, reworked components. In some cases, primary moulds are enlarged due to dissolution. The phytohermal travertine lithofacies forms an asymmetric, elongated mound structure at about the middle of the quarry (Fig. 5). In its thickest part it is up to $10-12 \mathrm{~m}$ high and $200 \mathrm{~m}$ in length. It has an asymmetric outline with steeper southern side (Fig. 5). Phytohermal travertine interfingers with other lithofacies both vertically and laterally (discussed below).

\subsubsection{Wavy laminated travertine}

Wavy laminated travertines consist of massive, white and brownish coloured laminae with elongated bed-parallel pores which are often partially filled by calcite cement and/or by infiltrated clayey material. The laminated structure is visualized by the variation of the darker brown and lighter brown laminae $(3-5 \mathrm{~cm}$ thick) as well as by layer parallel pseudo-fenestral pore-network occurring within but also separating the individual laminae from each other (Fig. 3C). The size of fenestral pores ranges between 0.5 and $2 \mathrm{~cm}$. The macroscopically observed lamination is the result of clotted micrite characterized by sparite dominated white, and micrite dominated dark laminae associated with horizontally elongated pores. Reworked intraclasts (1-3 cm in size), gastropod shell fragments and desiccation cracks are characteristic features of this facies. "In situ" reed and other macrophyte fragments occur randomly distributed but are not very common in this facies. Based on field observations, different types of wavy laminated travertine can be distinguished. On the northern side of the quarry, wavy laminated travertine facies is represented by parallel, more or less straight laminae with an average dip of $8-10^{\circ}$ to the NNW, whereas on the southern side, laminae are sloping to the SSE starting with a dip of about $15^{\circ}$ and increasing upwards. Consequently, the previously mentioned mound-like structure becomes apparent. Horizontally, this facies is present in maximum 1-3 m thick packages which is separated by units of massive travertine lithofacies (Fig. 6). The packages of wavy laminated lithofacies are traceable laterally over up to $80 \mathrm{~m}$ in distance (Fig. 5).

\subsubsection{Massive travertine lithofacies}

The second most dominant lithofacies is made up of structureless, massive brownish-greyish travertine, in which locally redeposited fragments of dark brownish "broken-up" layers, reworked lithoclasts and "black pebbles" occur (Fig. 3E). The size of these predominantly angular clasts ranges from $5 \mathrm{~mm}$ up to $2-3 \mathrm{~cm}$. The reworked lithoclasts and "black pebbles" are randomly distributed in massive travertine whereas the fragments of the brownish "broken-up" layers were also redeposited, however the original layer-like appearance is preserved.

Gastropod shells and redeposited phytoclast fragments are typical components of this facies. They are often "covered" by thin, maximum $1 \mathrm{~mm}$ thick, brownish micritic coatings. These coated fragments occur in horizontal wavy layers (Fig. 3E). Oncoid horizons were also observed in which oncoids of variable sizes $(0.5-4 \mathrm{~cm})$ occur. In the core of oncoids, mm-sized irregular-shaped fragments of redeposited clasts can be observed.

The massive travertine lithofacies is between 5 and $7 \mathrm{~m}$ thick and ca. $150 \mathrm{~m}$ in length. It is, however, split into two parts by the phytohermal travertine mound (Fig. 4). Vertically, the massive travertine is interrupted by intercalations of wavy laminated travertine, which horizontally interfinger with the phytohermal travertine.

In some cases, massive travertine vertically passes gradually into greyish travertine that is represented by dark greyish horizons in ca. $2-3 \mathrm{~m}$ thick packages (Fig. $3 \mathrm{~F}$ ). This facies is very homogenous and its texture likely was inherited from the initial massive travertine lithofacies. On top of these dark greyish horizons, light coloured massive unaltered travertine reappears. Within the dark greyish horizons some vertical, slightly branching, elongated Vshaped "patches" occur (Fig. 3F). These few centimetre long "patches" are distinguished on the basis of their colour and shape. Their textural characteristics were inherited from the host lithofacies. In some cases, horizons of "brain-like" branching pore structures (Fig. 3G) were observed in the greyish material. These branching pores are partly reduced by sparry calcite cement.

\subsubsection{Flat laminated travertine lithofacies}

Flat laminated travertine is built out of ca. $1 \mathrm{~cm}$ thick, almost straight laminae which are oriented parallel to each other. The laminated structure is discernible due to the alternation of dark greyish brown and light brown coloured laminae (Fig. 3D). There are no other macroscopic differences between the individual laminae (neither structurally nor texturally) and their boundaries are not sharply defined. The pore network is characterized by a preferential horizontal alignment. Macroscopically, these pores seem to be layer parallel and enlarged by dissolution in several cases. In contrast to the other facies, phytoclasts and gastropod shell fragments are absent. This lithofacies appears in the upper part of quarry, on the third, fourth and fifth excavation level. However, it can be properly observed only on the northern side of the previously described phytoclastic travertine. On the third excavation level, it is already present in the form of intercalations in the massive travertine with a layer-thickness of $0.3-1 \mathrm{~m}$. Structurally, from the fourth excavation level onwards (and in the fifth level as well) this facies forms an almost contiguous "homogeneous" geobody, on the average, a $10 \mathrm{~m}$ thick unit (Fig. 5). This lithofacies shows concordance with the massive travertine, and a discordance with the phytoclastic travertine. On the fifth excavation level the continuity of this facies is interrupted by interbedded units of massive travertine and its dip changes from $10^{\circ}$ to almost horizontal $\left(2-3^{\circ}\right)$. The transitions between lithofacies were overall gradual. Upwards this facies is bounded by a distinct exposure surface covered by loess.

\subsubsection{Marker horizons}

Some characteristic horizons occur and act as marker horizons. Along these horizons, dissolution phenomena occur together with breccias, irregular karstified surface morphologies as well as the accumulation of unconsolidated calcareous material (Fig. 4A). The alteration of the travertine host rock gradually fades within ca. 

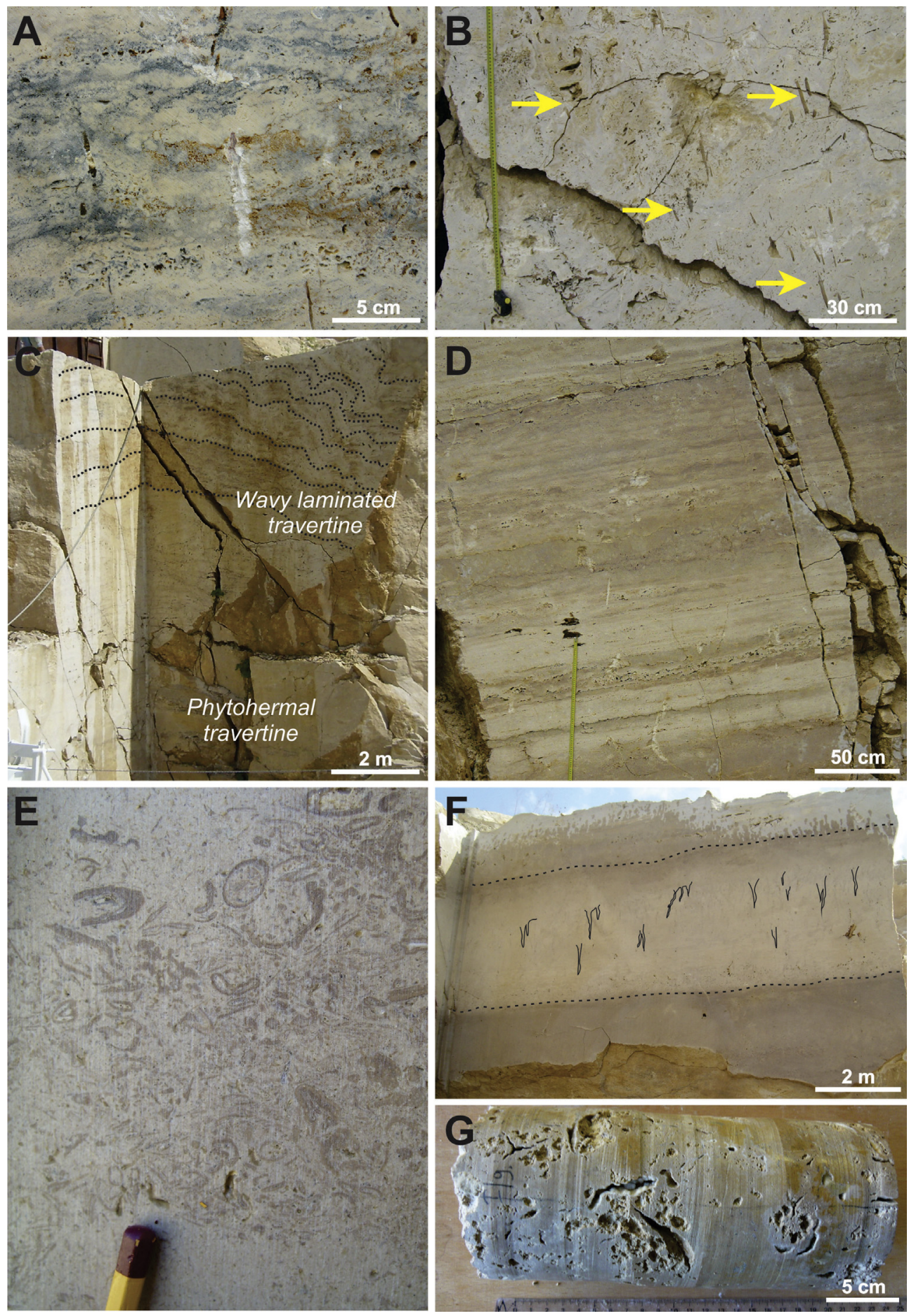

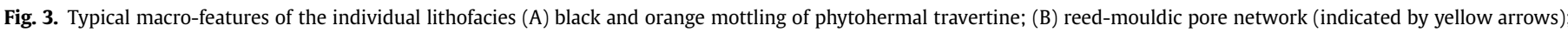

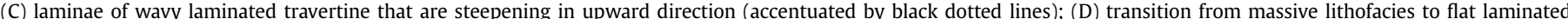

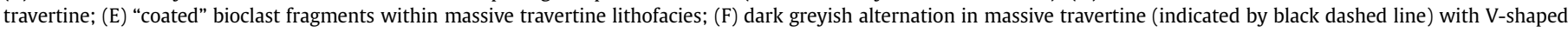

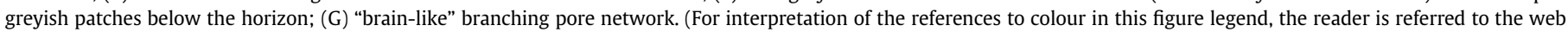
version of this article.)

0.3-0.5 $\mathrm{m}$ downwards from the marker horizon, which is a dissolution surface. In several cases at $50 \mathrm{~cm}$ below these marker horizons, secondary carbonate accumulation levels were observed that consist of whitish patches (Fig. 4A).

These horizons never intersect facies boundaries. Furthermore, their inclination is parallel to the layering of the individual lithofacies. They occur always within a specific facies but never constitute facies boundaries. Based on their inclination and positioning, two marker horizons were distinguished (Fig. 4B). The lower horizon (indicated by solid line in Fig. 4B) appears in any one of the lithofacies. This horizon is present on both sides of the phytohermal mound showing a dip of $10^{\circ}$ to the NW on the 

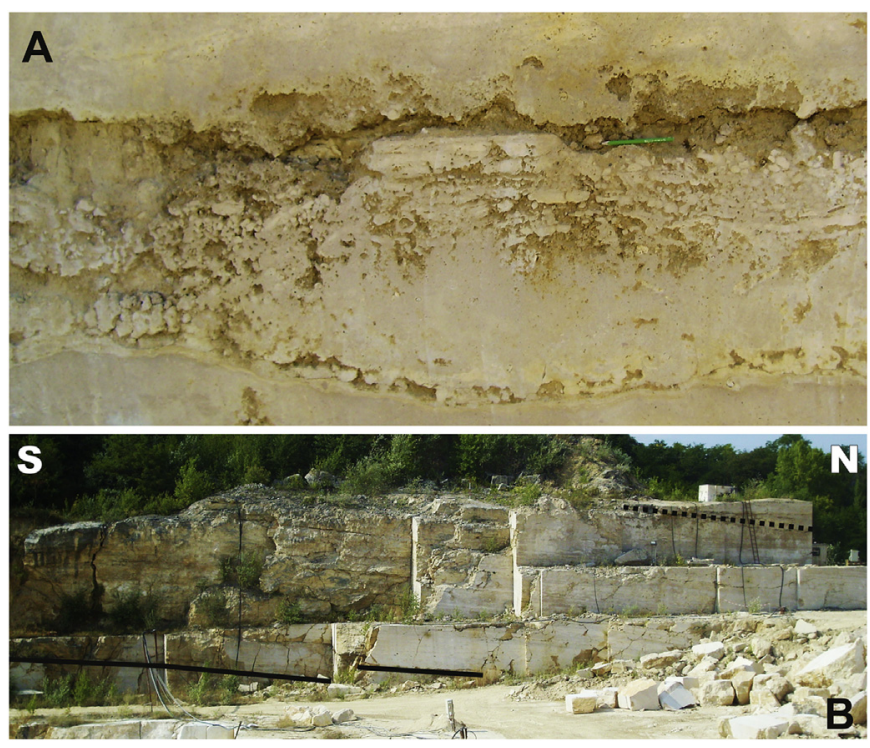

Fig. 4. Illustration of "Marker horizons". (A) layer parallel dissolution surface within massive travertine lithofacies. Along these dissolution surfaces, breccias, karstified, irregular surfaces and accumulation of calcareous unconsolidated material can be observed; (B) spatial separation of upper (indicated by black dotted line) and lower (presented by black solid line) "marker horizons".

northern side and $10^{\circ}$ dip to SE on the southern side. The upper horizon (dotted line in Fig. 4B) occurs only on the northern side of the phytohermal mound within the flat laminated travertine lithofacies exhibiting a similar dip to the NW.

\subsection{Spatial relationship of the identified lithofacies}

The phytohermal travertine forms an asymmetric moundshaped body in about the middle of the quarry. Hereby it divides the quarry into a northern and a southern part (Fig. 5). Vertically, it forms a contiguous unit which is bounded by flat laminated travertine from above. Exposure surfaces or any other distinctive boundaries have not been observed between the latter facies, however, onlapping relationships can be very well noticed along its borders. Laterally, the phytohermal travertine lithofacies shows some interfingering with wavy laminated travertine lithofacies and in some cases also with massive travertine lithofacies (Fig. 6).

Wavy laminated travertine occurs on both sides of the phytohermal travertine mound (Figs. 5 and 6). On the northern side, it is represented by more or less parallel layers with rather constant $\operatorname{dip}\left(\sim 10^{\circ}\right)$. On the southern side, however, the wavy laminated travertine facies displays some upward steepening dip of up to $\sim 15^{\circ}$ (Fig. 3C). Vertically, the continuity of facies is interrupted by units of massive travertine whereas laterally, it interfingers with both massive and phytohermal travertine lithofacies. With the exception of the fifth excavation level, wavy laminated travertine lithofacies is present on each level of the quarry.

Along with the phytohermal travertine, massive travertine lithofacies is another dominant facies of the Gazda quarry, which occurs on all quarry levels. This facies is present both on the northern and southern side of the phytohermal travertine and it is overlain by flat laminated travertine. Additionally, the inclination of the massive travertine corresponds to the inclination of wavy laminated and flat laminated travertine lithofacies which are similar with a dip of $10-12^{\circ}$ on both sides of the phytohermal travertine. The direction of inclination of both the wavy and the massive travertine lithofacies changes to the SSW on the southern side of the phytohermal travertine, whereas the inclination of flat laminated travertine above changes to almost horizontal.

The flat laminated travertine lithofacies is situated in the highest position inside the quarry, where it is mainly exposed in the fourth and fifth excavation levels. It appears also on the third excavation level concordantly interbedded within massive travertine lithofacies. On the fifth level, massive travertine lithofacies interrupts its continuation and the inclination of it becomes almost horizontal. A clear onlap was noticed between phytohermal and flat laminated travertine lithofacies on the southern side of the area where phytohermal travertine prevails (Fig. 6).

\subsection{Petrography}

On the basis of petrographic observations, three main textural types were distinguished that allow to describe the most common microscopic features of the above mentioned lithofacies: i.e. (1) micrite textures representing the primary fabric of the lithofacies; (2) micritic coatings; and (3) different types of clasts. Each major lithofacies is characterized by a particular association of these textural features and related cements (Table 1). These three textural types can be further subdivided (as indicated below with a respective code). The specific associations of the textural types characterise the different lithofacies/microfacies encountered.

\subsubsection{Textural group I - micrite}

Three distinct micrite sub-textures (M1 to M3) were identified on the basis of the micrite to sparite ratio and the kind of distribution between the micritic components. These micrite types are structureless and microporous, and consist of:

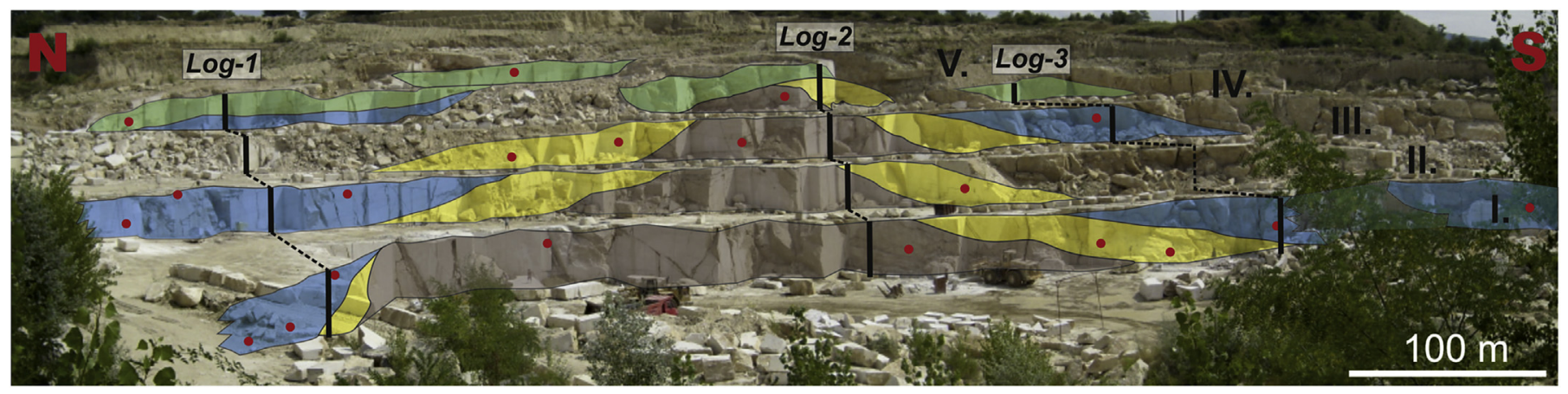

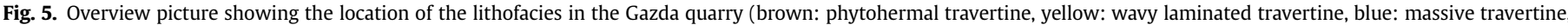

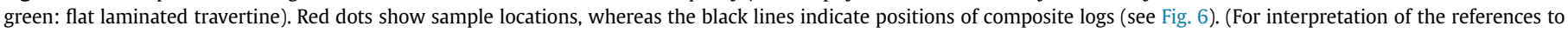
colour in this figure legend, the reader is referred to the web version of this article.) 


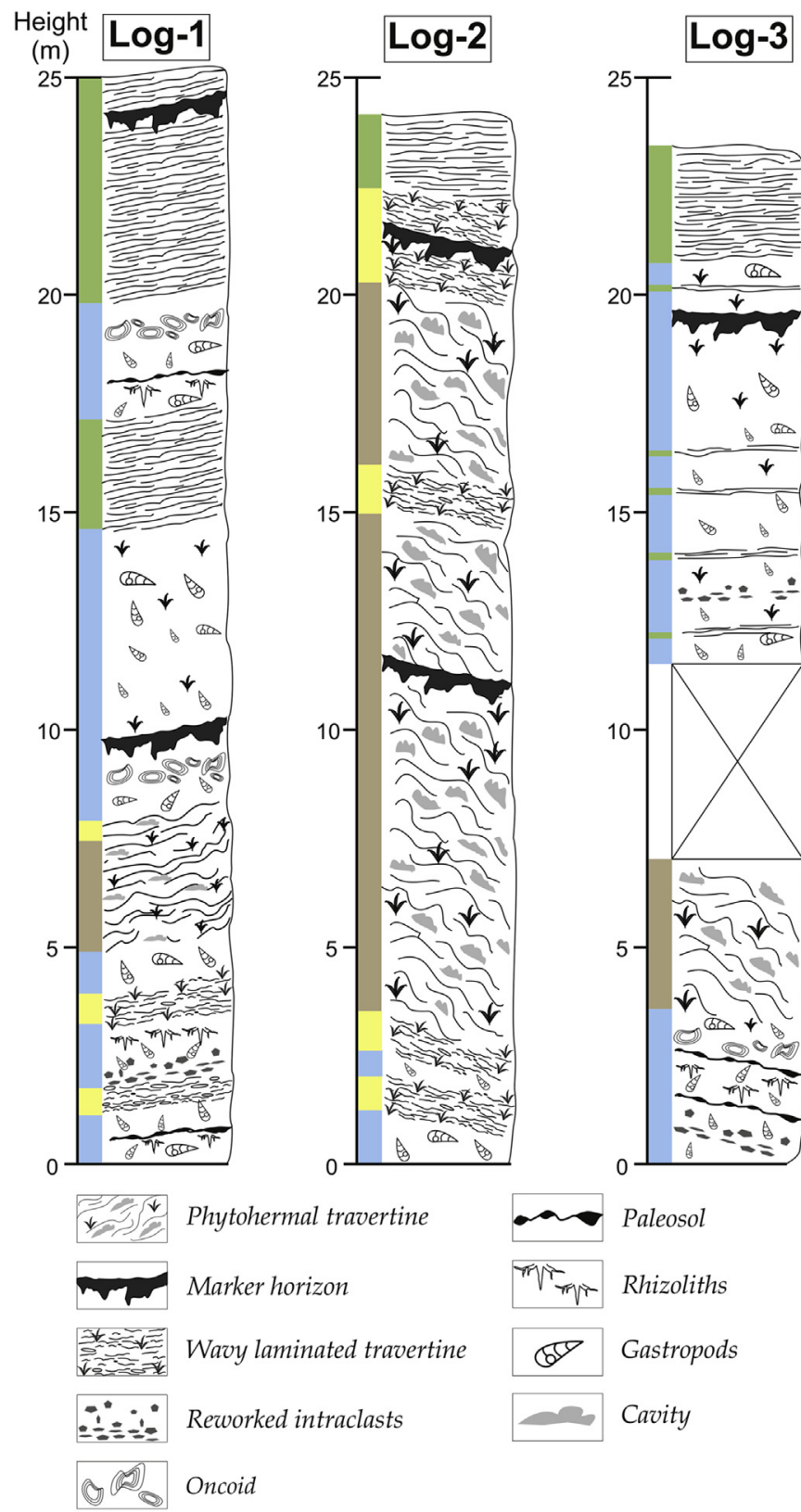

Fig. 6. Composite logs of the Gazda quarry (their locations are indicated with black line in Fig. 5). Colours illustrate the individual lithofacies (blue: massive travertine, yellow: wavy laminated travertine, brown: phytohermal travertine, green: flat laminated travertine). (For interpretation of the references to colour in this figure legend, the reader is referred to the web version of this article.)

M1 Dense micrite represented by an approximately homogeneous distribution of microcrystalline calcite phases that are less than $4 \mu \mathrm{m}$ in size (Fig. 7A). However, the latter phases often grade into clotted micrite. This dense micrite is marked by a low proportion of microsparite when compared to the other micrite types;

M2 Clotted micrite built up of sponge-like accretion of "micrite islands" (Riding, 2000) (Fig. 7B). The dark brown, fine crystalline calcite particles constitute clustered islands which are regularly connected to each other. In the middle of the individual "micrite islands", aggregations of even smaller carbonate phases can be observed. These central cores are represented by darker nodes which transform gradually into the rim of lighter brownish microspar. Via coupling of these "micrite islands" by microspar, clotted micrite texture is formed characterized by an overall irregular shape and distribution. In most cases, the clotted micrite is finally embedded in subhedral equant micro-as well as macrospar;

M3 Clumps of micrite consisting of well defined, isolated aggregations of small crystalline (carbonate) phases that are separated by sharp borders from the surrounding cement (Fig. 7C). Clumps range between 60 and $200 \mu \mathrm{m}$ in size and are also embedded in subhedral macrospar.

\subsubsection{Textural group II - micritic coatings}

Around primary fabrics and clasts, two micritic coatings ( $\mathrm{C} 1$ and C2) were observed, namely:

C1 Micrite coatings formed by dark brown and dense micrite that is present in the form of crusts of unequal thickness around micrite components (Fig. 7D). Their presence is seemingly random and their thickness varies between 20 and $100 \mu \mathrm{m}$;

C2 Micrite-sparite crusts built up of alternating micrite and sparite horizons. Directly on the surface of clasts, a brownish dense micrite can be observed (Fig. 7E), varying in thickness between 10 and $50 \mu \mathrm{m}$. This encrustation is overgrown by sparitic circumgranular calcite displaying undulose extinction. Within the latter sparite crusts, rounded micrite clouds, between 50 and $200 \mu \mathrm{m}$ in size, occur, displaying a random distribution. On top of the sparitic cement there follows again a dense micrite encrustation with a thickness of $\sim 30 \mu \mathrm{m}$. The alternation of these zones is repeated several times building up the micrite-sparite crusts.

\subsubsection{Textural group III - clasts}

Embedded in different types of primary fabrics, characteristic clasts were observed, namely:

CL1 Fan-shaped calcimicrobes lined up along 10-15 $\mu \mathrm{m}$ thick dense micrite horizons and possessing variable sizes with a maximum length of $1.2 \mathrm{~mm}$ (Fig. 7F). These unbranched microbial structures (see discussion) grew radially from certain nuclei within the micrite horizons;

CL2 Oncoids of highly diverse shape and size, occurring within clotted micrite (Fig. 7G). The size of these "constituents" ranges between $70 \mu \mathrm{m}$ to a few mm. They consist of a micrite core or a group of micrite clasts mixed with other constituents, such as ostracod shell fragments and phytoclasts, which are coated repeatedly by layers of dense micrite of various thicknesses (approximately 15-60 $\mu \mathrm{m}$ ).

CL3 Several intraclasts, corresponding to phytoclast fragments, ostracods and gastropod shell fragments (diameter of $200-500 \mu \mathrm{m}$ ) occurring within different types of micrite (Fig. $7 \mathrm{H}$ ).

The combinations of individual (sub-)facies as well as their characteristic cement and pore types are summarized in their order of dominance in Table 1.

\subsection{Diagenesis}

In the study area, the following diagenetic features were recognized:

Cementation, as the most important syn-diagentic process. The following cements could be distinguished: 
Table 1

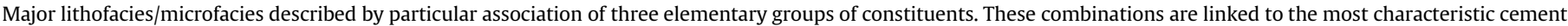
fillings and pore types.

\begin{tabular}{|c|c|c|c|c|}
\hline Lithofacies & Microfacies & Combination & Cement filling & Pore type \\
\hline \multirow{2}{*}{\multicolumn{2}{|c|}{ Phytohermal travertine }} & M1, M2 and sometimes & Equant-, drusy- and bladed macrospar. & Vuggy mesopores. \\
\hline & & $\mathrm{M} 3+\mathrm{CL} 3$ & Fan-like elongated crystals. & Phytomoulds. \\
\hline \multicolumn{2}{|c|}{ Wavy laminated travertine } & $\mathrm{M} 2+\mathrm{C} 1+\mathrm{CL} 3$ & $\begin{array}{l}\text { Circumgranular microspar.Equant macrospar. } \\
\text { Inclusion-rich bladed cement. }\end{array}$ & $\begin{array}{l}\text { Elongated, layer parallel pores. } \\
\text { Irregular, meso- and } \\
\text { macropores. }\end{array}$ \\
\hline \multirow{4}{*}{$\begin{array}{l}\text { Massive } \\
\text { travertine }\end{array}$} & Intraclastic grainstone & $\mathrm{M} 3+\mathrm{C} 1+\mathrm{CL} 3$ & Subhedral macrospar, fibrous calcite. & Interparticle mesoporosity. \\
\hline & Oncoid travertine & M1 and M2 + CL1 CL.2 & $\begin{array}{l}\text { Bladed, dogtooth and equant subhedral macrosparitic } \\
\text { calcite. }\end{array}$ & Framework porosity. \\
\hline & $\begin{array}{l}\text { Peloidal intraclastic } \\
\text { travertine }\end{array}$ & $\mathrm{M} 2$ and $\mathrm{M} 3+\mathrm{C} 1+\mathrm{CL} .3$ & Subhedral macrosparitic calcite. & Intergranular mesoporosity. \\
\hline & Clastic travertine & $\mathrm{M} 1+\mathrm{C} 1 ; \mathrm{C} 2+\mathrm{CL} 1$ and CL2 & $\begin{array}{l}\text { Blocky cement. } \\
\text { Drusy, anhedral calcite. }\end{array}$ & Interparticle porosity. \\
\hline \multicolumn{2}{|c|}{ Flat laminated travertine } & M2 & Equant subhedral macrospar. & Framework porosity. \\
\hline
\end{tabular}

- Fan-shaped, elongated crystals being the most characteristic cement type of the phytohermal travertine lithofacies. The crystals exhibiting sweeping extinction surround the phytomoulds that are sometimes millimetre-sized. These crystals are growing radially from a certain nuclei that are lined up around phytomoulds (Fig. 8A).

- Bladed calcite cements occurring predominantly in horizontally elongated irregular mesopores. They are growing outward from the bottom of pore walls (Fig. 8D).

- Equant subhedral macrosparry calcite cements, which are one of the most common cement types in the Gazda quarry, occurring in vugs and framework pores (Fig. $7 \mathrm{H}$ ).

In the $\mathrm{CL}$ microscope, with the exception of the fan-shaped crystals, alternation of non-luminescent and luminescent bands can be observed within these cements (Fig. 8C).

Dissolution features can be observed both macroscopically and microscopically in the studied carbonates. Macroscopically they are especially manifested within the "Marker horizons". Within the intercrystalline pore space, dissolution is represented by rounded crystal edges as observed under SEM whereas in the case of the different micrite types, convexity and sharp edges of micrite grains may reflect dissolution (Fig. 8C). CL microphotographs sometimes also clearly show dissolution features at corroded contacts of porefilling calcite cement crystals represented by scattered and pinching out luminescent zones (Fig. 8F).

Except for the flat laminated travertine lithofacies, recrystallization is a common phenomenon in all continental carbonates of the Gazda quarry. Here, primary clotted micrite is replaced by an anhedral mosaic fabric in several cases (Fig. 8H,I). Another form of recrystallization was recognized, in solid-inclusion-rich calcite crystals with irregular crystal edges occurring within the primary micritic fabric (Fig. 8B). This type of texture displays a distinct mottled orange luminescence (Fig. 8B,C).

Sparmicritization was also observed. In case of the massive travertine lithofacies (within clastic travertine subfacies, Table 1), partial micritization of sparite zones was detected within the micrite-sparite crusts, which now correspond to randomly distributed rounded micrite clouds of various sizes (Fig. 7E). The origina clotted micrite textures are represented as ghost textures in some cases (Fig. 8H,I). In the CL microscope these crystals locally display a weak mottled luminescence. This structure can be a result of recrystallization and/or sparmicritization (Fig. 8B,C) (see discussion).

Along with dissolution, also the decomposition of organic matter clearly provides additional space for subsequent cement precipitation. The latter obviously has a significant impact on porosity and permeability that is important in the case of the phytohermal travertine lithofacies. Mould development results in the creation of rounded phytomoulds that are partly filled by subsequent calcite cement. In case of the clastic travertine subfacies, V-shaped, branching mouldic mesopores developed that could have been formed by root decay (Fig. 8D,G). These mouldic pores are cement-reduced, the cement crystals display a bladed and equant mosaic habit (Fig. 8D,E,G).

\subsection{Deformational features}

Several faults with normal and reverse displacement, as well as sediment-filled fractures and mineral veins were observed in the Gazda quarry. Measured structural elements were plotted on stereograms using the software of Angelier (1984). The direction of extension was estimated using the simple geometrical assumption of Anderson (1951) based on tensional fractures, conjugate faults and the main stress axes.

Based on field observations and measured data, seven fracture groups can be distinguished (see Fig. 9). These groups represent successive events, while overprinting relationship can also be observed (see blue arrows on Fig. 9). Fractures were opened and filled as sedimentary fractures, while fracture infill was sometimes fractured again. Faults at the west-facing entrance of the quarry are separated in space and therefore they can hardly be integrated into a temporal scheme (indicated as $2-3$ in Fig. 9).

The oldest observed structure corresponds to a moderately $\left(45-60^{\circ}\right)$ dipping surface between the travertine and the younger loess, observed in the western corner of the quarry. Here the loess, although it is younger, is exposed topographically below the travertine (Fig. 10). The surface in between the two is slightly wavy, likely due to some dissolution. The observed peculiar structure between the travertine and the younger loess can be interpreted as the result of a complex evolution.

The dip of the strata reflects a bowl-shape or synformal geometry of the travertine body exposed in Gazda quarry. In the NNW corner of the first excavation level, the travertine is displaced by several SE-dipping faults (Figs. 9 and 11B). They are associated with wall-perpendicular opening and sediment infill and can tentatively be considered as "hybrid" faults (sensu Hancock, 1985), corresponding to a combination of shearing and wallperpendicular opening. Fracture walls were first coated with isopachous calcite and subsequently by loess-derived infill from above (Fig. 11A). Faults reach the underlying clastic sediment, but their continuation downward cannot be evaluated. These structures resemble domino style faults (Fig. 11A).

The travertines were generally deformed by several steeply dipping faults. They are mostly NE-SW trending, although $\mathrm{N}-\mathrm{S}$ and 

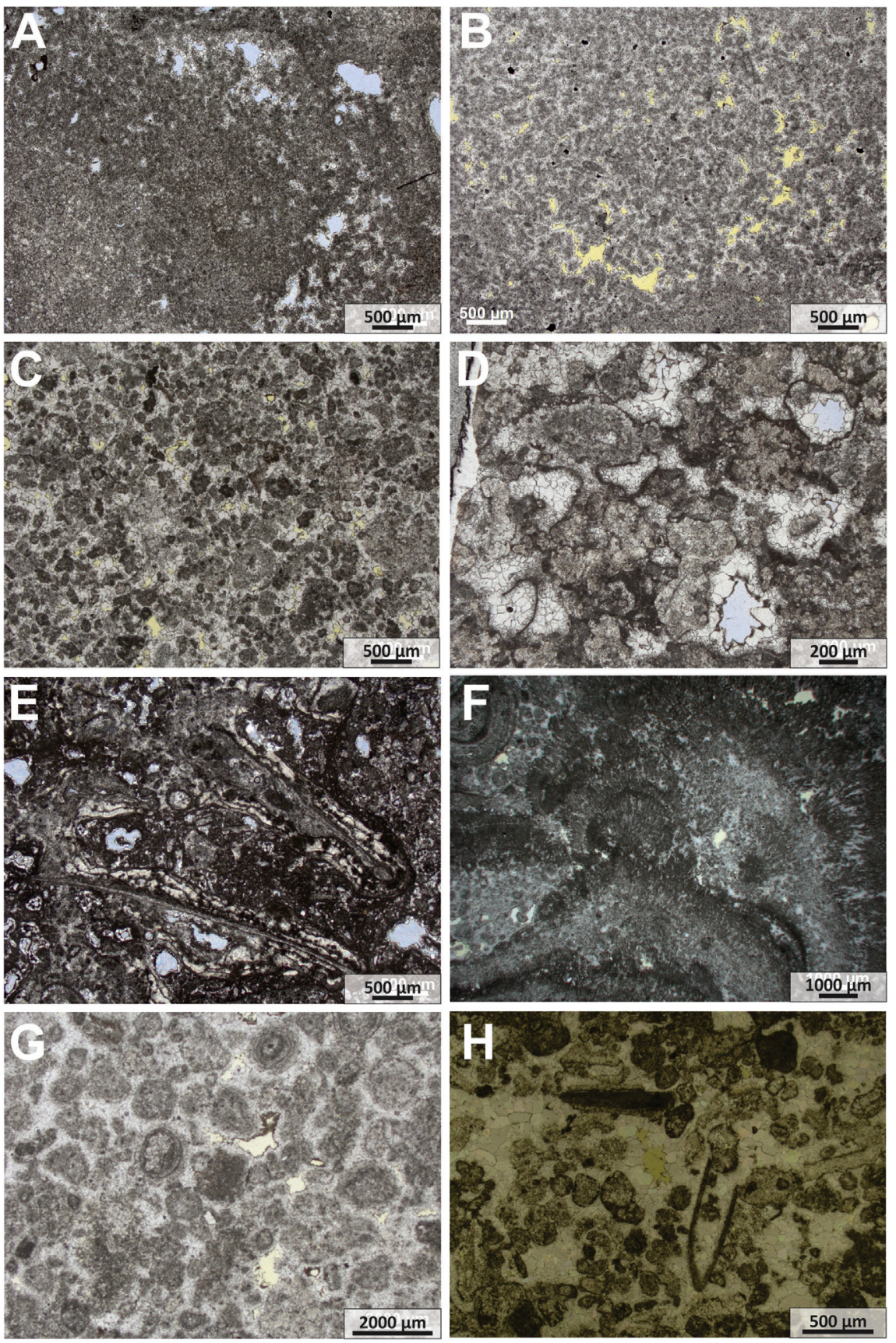

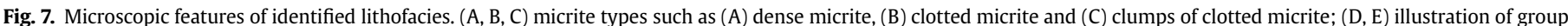

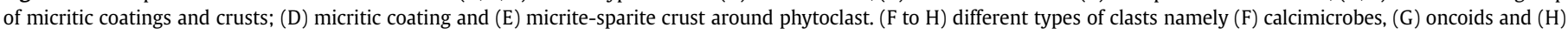
intraclasts.

E-W striking faults also occur (Fig. 9). They are either straight, relatively planar or composed of zig-zag segments with steep and sub-vertical geometry (Fig. 12A and C). Displacement can reach $1.5 \mathrm{~m}$. Kinematics of the faults can be deduced from the displaced beds (such as marker horizons) and also from 10 to $100 \mathrm{~cm}$ long pull-apart "jogs" along the faults. Both normal and reverse kinematics could be established (Fig. 12A-C). Along normal faults the pull-apart jogs are sub-vertical (Fig. 12C). Along reverse faults, the opened fractures are moderately dipping while sheared segments are steeper (Fig. 12A and B). Some joints without noticeable displacement show symmetrical geometry with respect to the inclined bedding. The latter are interpreted as shear fractures (Fig. 12D).
A large number of sediment-filled fractures are present in the quarry (Fig. 13). Their width varies from 10 to $50 \mathrm{~cm}$, but several 1-1.5 m wide fractures also occur, and the largest sediment-filled fracture is $6-7 \mathrm{~m}$ wide (Fig. $13 \mathrm{~A}$ and $\mathrm{C}$ ). The infilling of the large-scale fractures consists mostly of unconsolidated loess or fine sand, occasionally sandy silt with gravel, sometimes with angular travertine clasts (Fig. 13B). In one occasion gravelly sandstone was also observed, resembling young terrace deposits found in the overlying exposures. In the widest fracture, rounded quartz pebbles of 1-10 cm diameter are present. They either originate from Quaternary terrace gravel or possibly from Paleogene clastic formations which could have been exposed in the surroundings at the time of the infill of the fracture, due to uplift of the latter strata. 

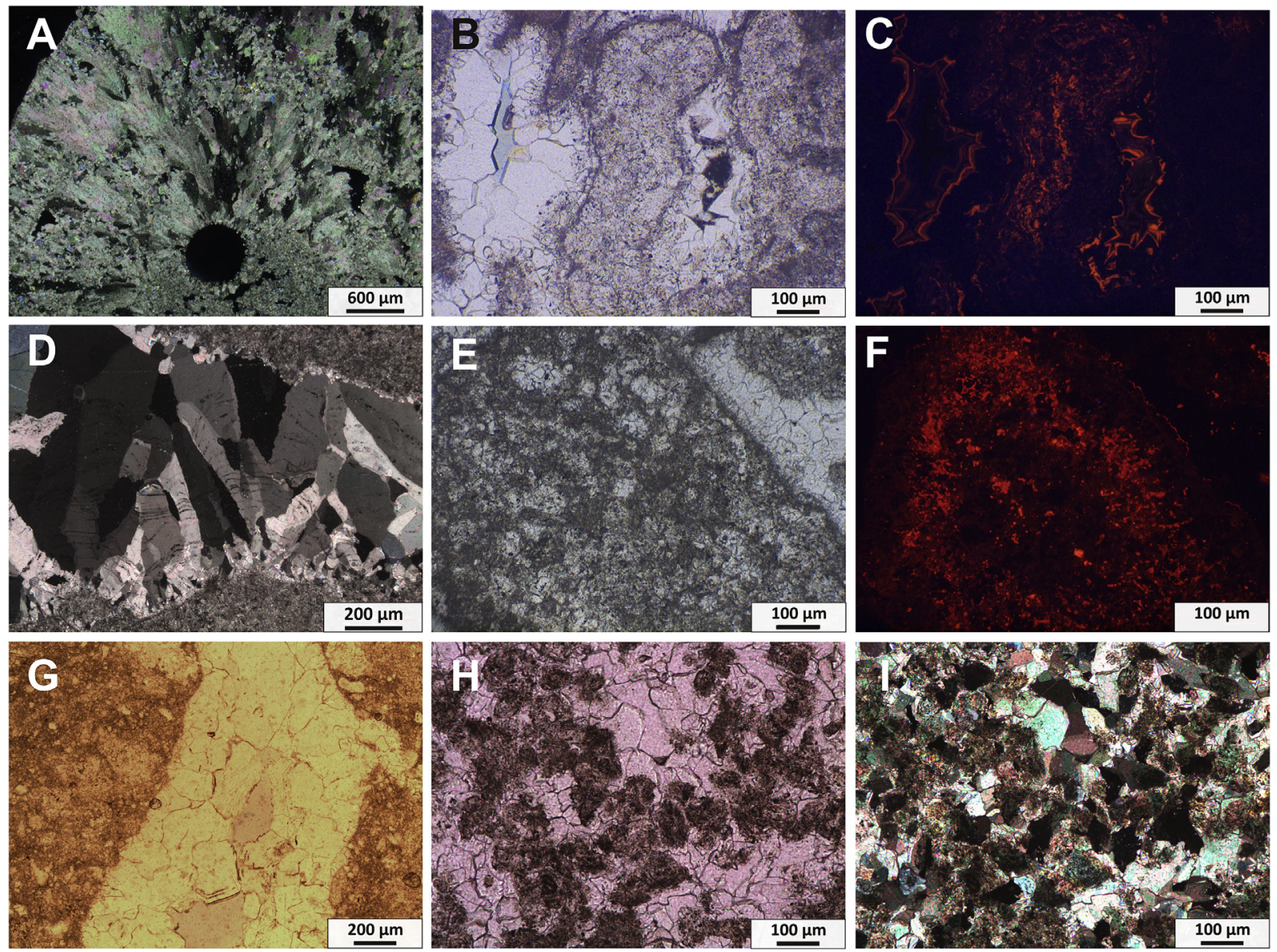

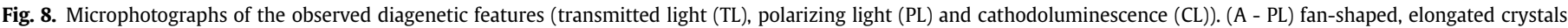

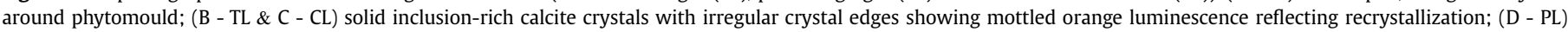

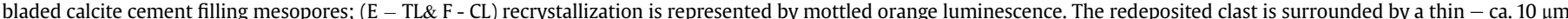

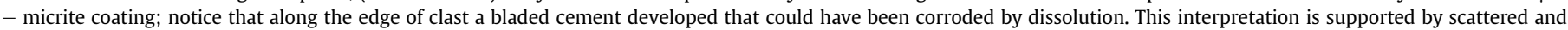

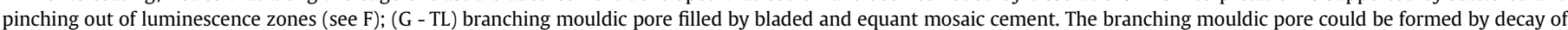

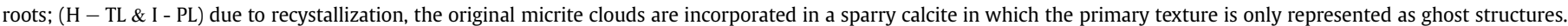

\subsection{Stable oxygen and carbon isotopes}

The $\delta^{13} \mathrm{C}$ values show an average of $-0.42 \% \pm 0.97$ (V-PDB) (ranging from $--3.38 \%$ to $+0.44 \%$ ), whereas the $\delta^{18} \mathrm{O}$ values cluster around a mean value of $-11.59 \%$ \pm 0.67 in V-PDB (from $-12.44 \%$ to $-10.41 \%$ ). The micrite and cement phases differ slightly in their isotope values, i.e. micrite phases possess an average varying around $\delta^{18} \mathrm{O}=-11.52 \%$ and $\delta^{13} \mathrm{C}=-0.27 \%$, whereas the cement phases cluster around an average $\delta^{18} \mathrm{O}$ and $\delta^{13} \mathrm{C}$ of $-11.75 \%$ and $-0.79 \%$, respectively.

When stable isotope values of the individual lithofacies are compared, some slight differences can be observed (Table 2). The massive travertine lithofacies display somewhat higher average $\delta^{18} \mathrm{O}$ and $\delta^{13} \mathrm{C}$ values than all the other lithofacies (i.e. $\delta^{18} \mathrm{O}=-11.30 \%$ o, $\delta^{13} \mathrm{C}=-0.19 \%$ ). In contrast, phytohermal travertine lithofacies represent the lowest average $\delta^{18} \mathrm{O}$ and $\delta^{13} \mathrm{C}$ signatures $\left(\delta^{18} \mathrm{O}=-11.81 \%\right.$, $\delta^{13} \mathrm{C}=-0.69 \%$ ) whereas the wavy laminated and flat laminated travertine lithofacies are represented by almost average $\delta^{18} \mathrm{O}$ and $\delta^{13} \mathrm{C}$ signatures (wavy laminated travertine: $\delta^{18} \mathrm{O}=-11.64 \%$, $\delta^{13} \mathrm{C}=-0.23 \%$ and flat laminated travertine: $\delta^{18} \mathrm{O}=-11.62 \%, \delta^{13} \mathrm{C}=-0.66 \%$ ).

\section{Discussion}

\subsection{Depostional environment of the individual lithofacies}

Structural geological observations suggest that the relative position of the travertine bodies in the Süttö travertine complex has not changed much since deposition, i.e. Pleistocene times. Borehole-evidence (locations indicated in Figs. 14 and 15) shows that below the top of Haraszt Hill there is no travertine. Under $5-10 \mathrm{~m}$ of loess, boreholes penetrated $35-40 \mathrm{~m}$ of Mio-Pliocene siliciclastics (mainly clay with occasional pebbles, rock fragments and some sand), immediately underlain by the Mesozoic (mainly Jurassic) limestone basement (Figs. 14 and 15). Similar clayey, gravelly beds (possibly overlain by a thin veneer of early Quaternary terrace sediments) were exposed by the mining operations below the travertine of the Gazda quarry.

As shown by the geometry of the travertine beds (Fig. 16), the antecedent land-surface was probably a valley with a gentle slope to the SSW with some smaller-scale topographic irregularities. The relative position of the quarries and the observed general synform arrangement of the travertine sequences corroborate the idea of an 

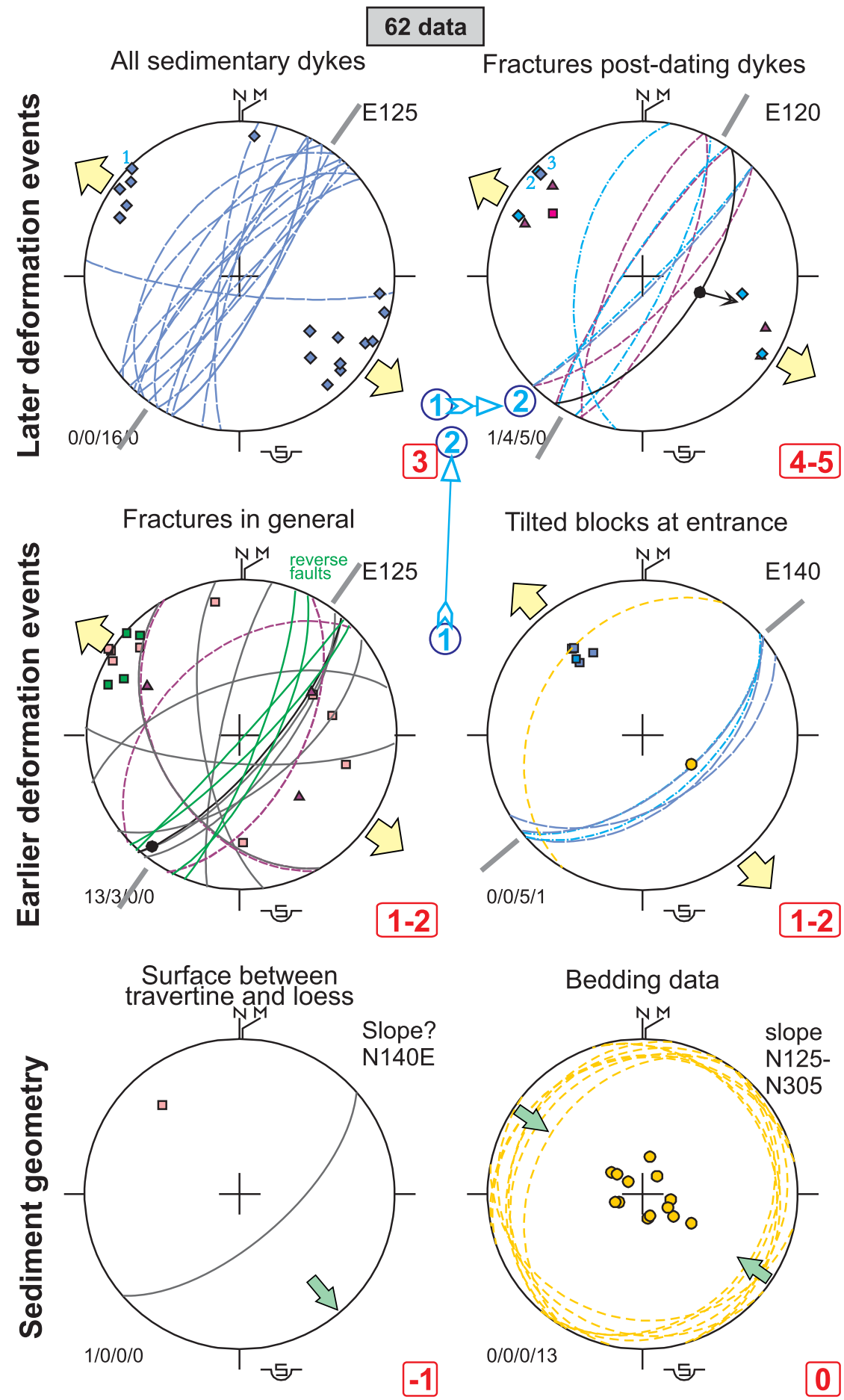

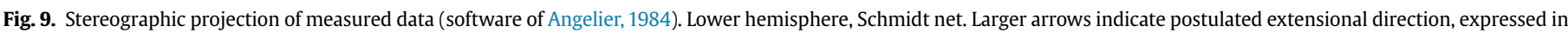

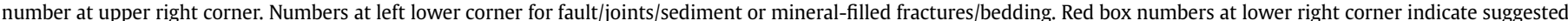

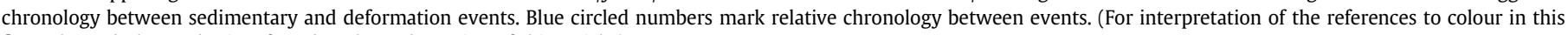
figure legend, the reader is referred to the web version of this article.)

ancient valley (Fig. 16).

The borehole logs of Haraszt Hill indicate that the juxtaposed Gazda travertine is situated at an elevation lower than the Mesozoic core of the hill suggesting that there is probably a fault in-between the two (Fig. 15). This supposed fault could have provided favourable pathways for waters of the Mesozoic reservoir to discharge. Facies distribution and the geometry of the travertine bodies suggest that one of the groundwater discharge points feeding the Gazda-Hegyhát travertine system (described by Figs. 5, 14 and 15) must have been to the east of Gazda quarry and another one was probably located between the Óharaszt and Hegyhát quarries (Fig. 14).

The actual relative topographic position of the quarries shows that the abandoned Óharaszt quarry is situated at the highest 


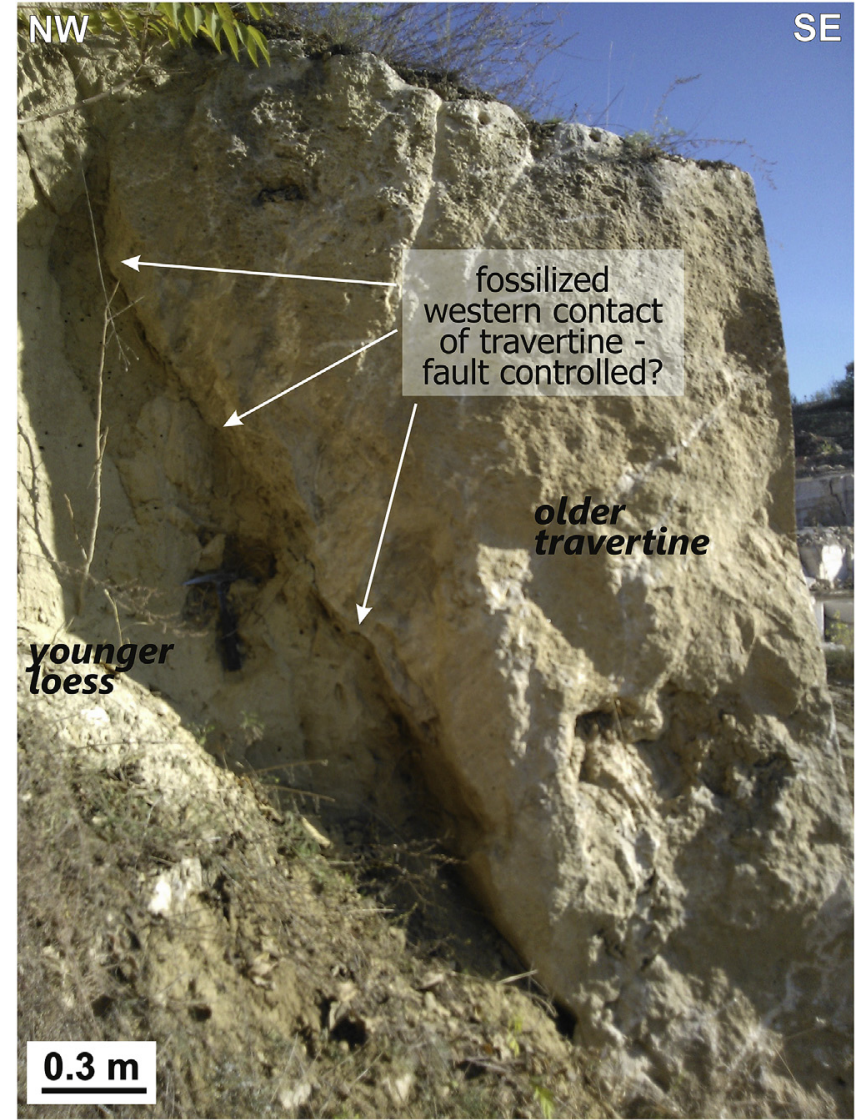

Fig. 10. Contact of the travertine and Late Pleistocene loess at the north-western margin of the Gazda quarry. For interpretation see discussion section.

elevation whereas both the Hegyhát and the Gazda quarries occur at slightly lower levels (Fig. 14). Based on this, it can be suggested that these latter two were deposited from springwater flowing downwards into the valley of the ancient Bikol-creek (Figs. 1 and 14) corresponding to the local base level of erosion probably already in Pleistocene times.

As pointed out in the results section, the position of the phytohermal travertine lithofacies has primarily controlled the spatial development of all the other lithofacies exposed in the Gazda quarry (Fig. 5). The phytohermal travertine is strikingly similar to the reed mound facies described by Guo and Riding (1998), as it is characterized by abundant growth of reeds and grasses forming an asymmetrically developing mound. These authors suggested that travertine formation, when taking place over a significant topographic relief may grow outward from a prograding slope. In case of the Gazda quarry, it is suggested that it was such an irregularity which became colonized by hydrophilic plants (e.g. reeds) and thus the incipient mound developed. Due to fast $\mathrm{CO}_{2}$ degassing, the fluid became oversaturated with respect to calcite which resulted in more and more swift inorganic carbonate precipitation around the reed stems resulting in high-intensity carbonate-precipitation and the gradual progradation of the mound.

The colonization by hydrophilic plants was apparently able to keep pace with the progradation of the reed-stabilized mound. Some evidence of fast carbonate precipitation was also observed in the thin sections. For example in the phytohermal travertine lithofacies, fan-shaped crystals were observed around phytomoulds preserving the shape of the original phytoclasts even after their decay (Fig. 8A). The precipitation in this case must have been, indeed, driven by rapid degassing of $\mathrm{CO}_{2}$ (cf. Given and Wilkinson, 1985). Carbonate particles, entrapped within the intercrystalline pore space, were apparently transported and redeposited by the fast flowing water.

The wavy laminated travertine facies occurs on both sides of the phytohermal travertine mound representing a similar slope depositional environments (Fig. 5). The absence of signs of substantial sub-aerial exposure suggests that water supply must have been (semi-) continuous. Different flow conditions established on the slope of the mound resulted in different types of wavy laminated travertine lithofacies associated with it. The northern slope of the mound is characterized by almost parallel, less wavy laminae with a dip of $10^{\circ}$ to NNW. It suggests that the northern slope of the phytohermal mound had a smoother surface with less turbulence of the water flow (c.f. Guo and Riding, 1998). In contrast, the southern slope of the mound likely had a more significant surface roughness that is represented by wavy laminae with variegated inclination displaying some upward steepening dip ( 15 $\left.{ }^{\circ}\right)$ (Fig. 3C).

Based only on its macroscopic characteristics, the wavy laminated travertine lithofacies is very similar to the smooth slope facies as defined by Guo and Riding (1998), however, there are microscopic differences. In contrast to the crystalline crust dominated smooth slope facies of Guo and Riding (1998), the wavy laminated travertine of the Gazda quarry is characterized by clotted
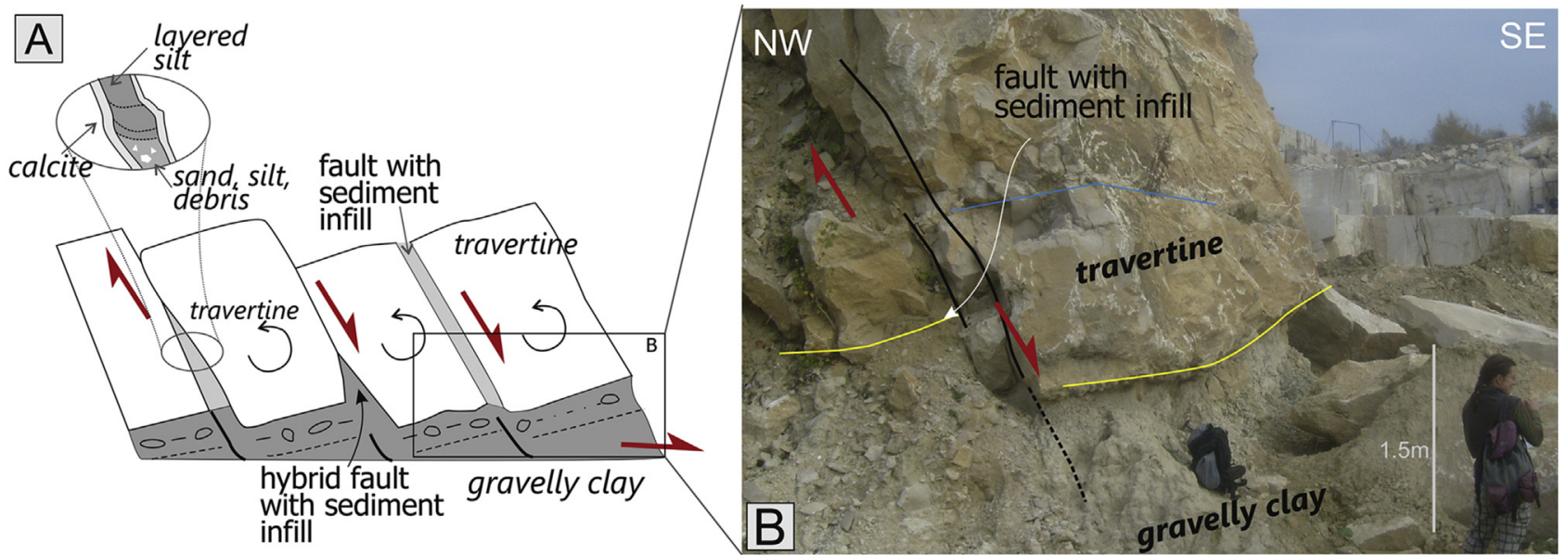

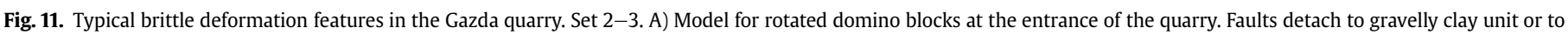
deeper clay/silt; B) detail of the edge of tilted blocks, with sediment-filled fault. 


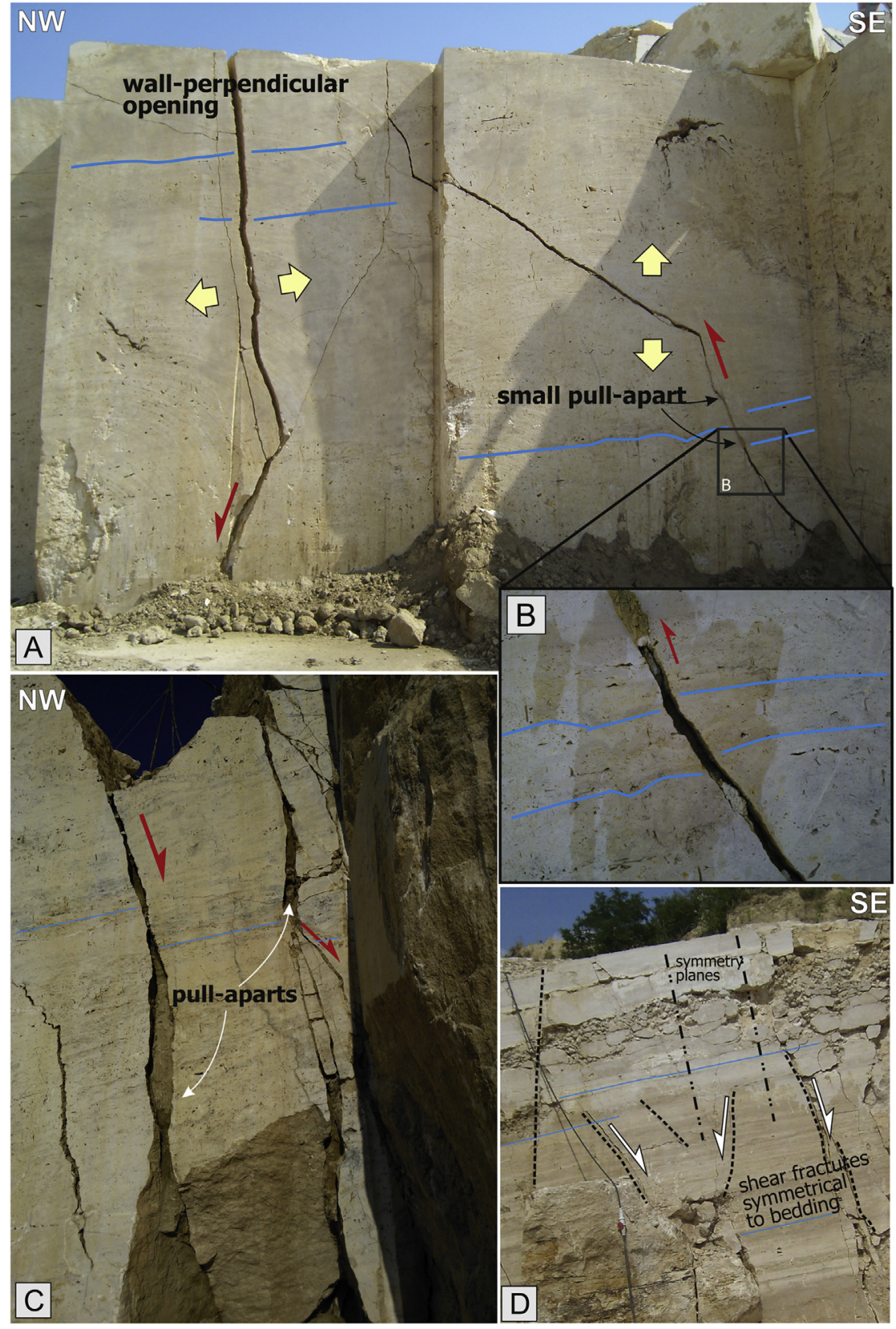

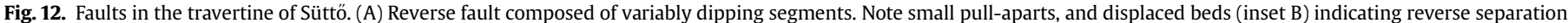

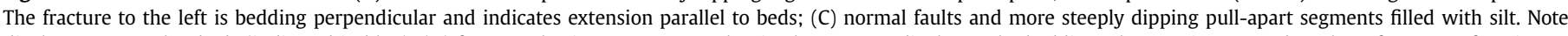

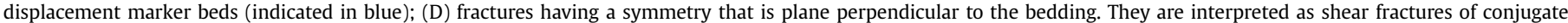
geometry. (For interpretation of the references to colour in this figure legend, the reader is referred to the web version of this article.)

micrite that may indicate relatively slower carbonate precipitation.

According to Gierlowski-Kordesch (2010) massive carbonates are "composed of structureless fine-grained carbonates that may contain preserved fauna and flora" and they are a common lithofacies in lacustrine environments (Arenas et al., 1997; GierlowskiKordesch et al., 1991; Alonso-Zarza and Wright, 2010). The definition fits to the massive travertine lithofacies of Gazda quarry representing sub-aqueous deposition. Field observations show that massive travertine lithofacies occurs on both sides of the phytohermal travertine mound and laterally interfingers with the wavy laminated travertine lithofacies. After passing over the mound, the overflowing water could have encountered another topographic obstacle to the south-southwest causing the establishment of a subsequent pond environment in-between the two topographic highs (Fig. 17). Unfortunately, however, the present state of the quarry does not allow to observe directly such a topographic obstacle. Alternatively, the observed massive travertine lithofacies on the two sides of the mound could have been deposited within one and the same lake/pond, however, the existence of multiple ponds cannot be excluded either.

The pond sequences are characterized by the development of massive travertine lithofacies, in which transported phytoclasts, gastropods and ostracod fragments accumulated. Slight variations in colour and sedimentary structures within the massive travertine body indicate changes in depositional conditions. Within this facies repeated occurrence of altered dark greyish horizons may reflect 


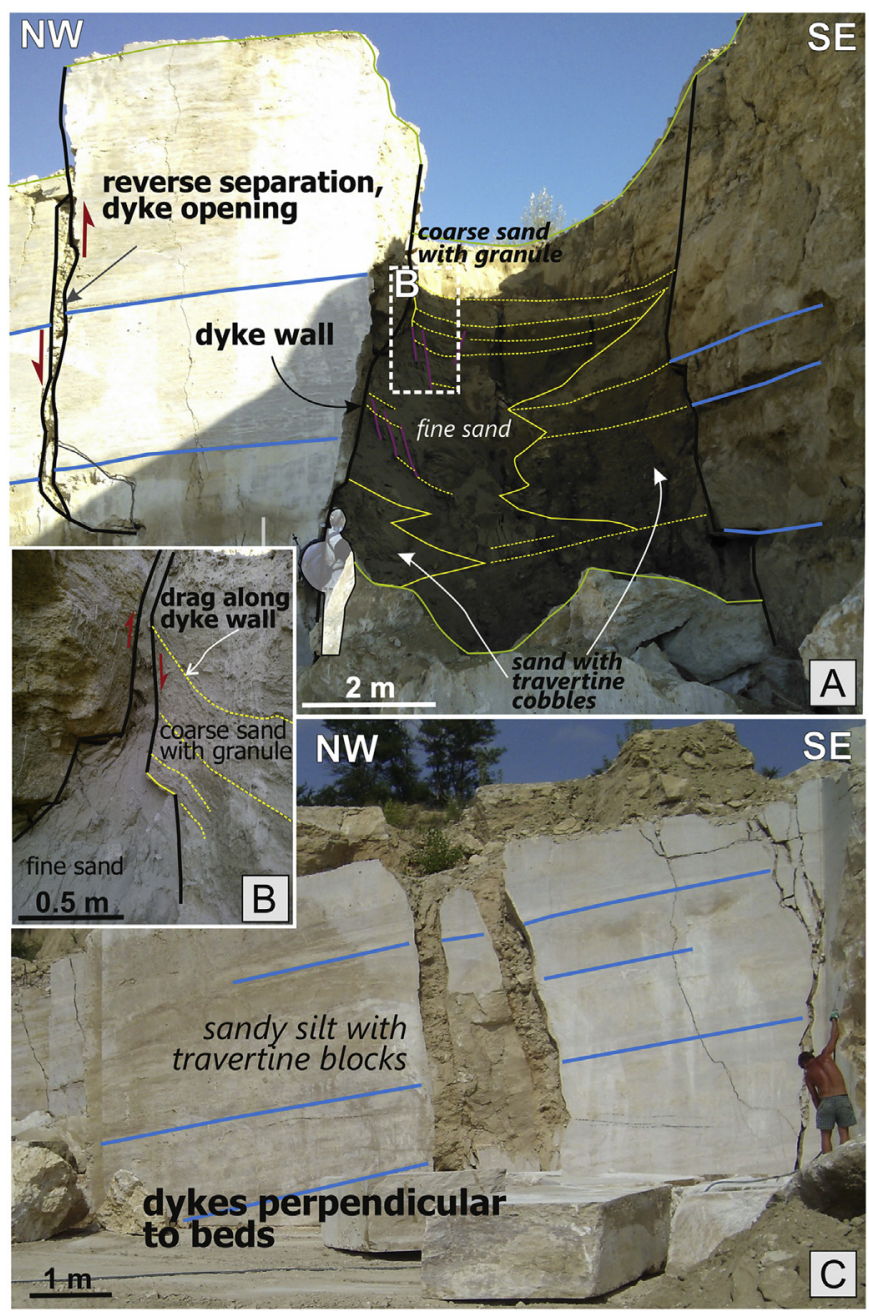

Fig. 13. Sediment filled fractures in the travertine. (A) The widest sedimentary fracture has been filled with variegated clastics; (B) infill has been affected by dragging along fracture walls and minor faults and joints; (C) fractures are perpendicular to the bedding and are filled with travertine cobbles embedded in sandy silt matrix.

water-level fluctuations (Platt and Wright, 1991; Freytet and Verrechia, 2002; Alonso-Zarza and Tanner, 2010) (Fig. 3F). As a result of the decreasing water level, the shallower (marginal) areas of the pond(s) could have been converted even into some palustrine environments. Formerly deposited lacustrine sediments thus intermittently became exposed and pedogenic processes modified their original texture. In these areas the light brownish colour of the massive travertine lithofacies changed to greyish (Fig. 3F), presumably due to the increased contribution of organic matter. Additionally, the observed vertical, sometimes branching V-shaped structures indicate hydrophilic plants which colonized the newly established palustrine environment (cf. Freytet and Plaziat, 1982). Since well-developed paleosol horizons were not observed, the sub-aerial exposure must have been ephemeral. The repetition of the dark greyish horizons, however, denotes multiple water-level fluctuations.

Flat laminated travertine is situated in the highest stratigraphic position within the quarry where it is interbedded with massive travertine (Figs. 3D and 4). Macroscopic and microscopic observations suggest that the flat laminated lithofacies was deposited within shallow ponds. At the third excavation level, a clear onlapping was noticed between the phytohermal and the flat laminated travertine facies on the southern side of the phytohermal travertine mound. Onlapping suggests that this laminated travertine could have been deposited from waters originating somewhere in the eastern part of the pond-slope-mound system. The laminated travertine became interfingered with the other pond deposits, which precipitated from the water coming from north-east and flowing along the axis of the main valley. The mound could have been constructed at about the confluence of the two water courses.

The "Marker horizons" correspond to dissolution (karst) surfaces. The formation of dissolution breccias and karst development resulted in an irregular surface morphology with accumulation of a thin veneer of unconsolidated calcareous material (Fig. 4). According to the dip of these surfaces two main Marker horizons can be distinguished indicating two relatively longer-lasting interruptions of the spring activity. They show that carbonate precipitation stopped and karstification took over, obviously resulting from the infiltration of waters undersaturated with respect to calcite. Similar dissolution horizons can be observed also in the Újharaszt quarry (location see Fig. 1). This shows that unlike the palustrine episodes observed in the massive travertine facies, the "Marker horizons" are well-developed subaerial exposure surfaces, and therefore reflect a more substantial pause in spring activity.

\subsection{Microbial origin of the fabrics}

The primary fabric is predominantly represented by dense, clotted micrite and clumps of clotted micrite (Fig. 7A-C). According to Riding (2000), microbes play an important role in the formation of different types of micrite. Riding (2000) interpreted the formation of dense micrite as the result of calcified bacterial cells. However it can also be formed via abiotic "whitings" (sensu Tucker and Wright, 1990). After death, bacteria become calcified (Krumbein, 1979) forming small rounded clots. These rounded bodies can be the evidence of nanobacteria (Folk, 1993). However, calcification of biofilms around grains may also generate dense micrite (Riding, 2000). According to Riding and Tomás (2006), clotted micrite represents products of organic decay immediately below the sediment-water interface, i.e. they are early diagenetic in origin. The aggregates and the open-space fabric between them reflect the spatial distribution of the original bacterial colonies in the degrading organic matter. A similar process can be supposed in case of the formation of other types of micrite. The formation of micrite clumps is probably the result of reworking of clotted or dense micrite.

The development of micritic coatings around primary fabrics and clasts may relate to micritization (Fig. 7D). According to Tucker and Wright (1990) a micrite envelope around grains may represent an early stage of micritization caused by endolithic microbes and fungi. In the course of this process the grains are bored along the edges by microbes and the created holes become filled by fine grained sediment or fine cement. Depending on the activity of endolithic microbes, grains can be even completely micritized. Micritization by microbes and fungi can take place everywhere, however, this process is more dominant in calm environments where the movement of sediment-particles or pore-fluids is slow (Tucker and Wright, 1990). According to petrographic investigation of this study, micritic envelope development was especially abundant in the wavy laminated travertine lithofacies on the proximal side of the phytohermal mound and in the massive travertine lithofacies which both may represent deposition in a shallow, calm environment.

The development of a micritic-sparitic crust around phytoclasts may be the result of biological activity on plants (Fig. 7E). The role of plants in biological weathering is well-known (Keller and Frederickson, 1952; Wright and Tucker, 1991). The adhering water film around plant roots is primarily acidic. Consequently weathering (dissolution) of the carbonate dominated host rock/sediment 
Table 2

Stable carbon and oxygen isotope values from Gazda quarry with calculated temperatures and origin of $\mathrm{CO}_{2}$.

\begin{tabular}{|c|c|c|c|c|c|c|c|c|}
\hline Sample name & Lithofacies & $\begin{array}{l}\delta^{13} \mathrm{C}(\mathrm{V}- \\
\mathrm{PDB}, \% 0)\end{array}$ & $\begin{array}{l}\delta^{13} \mathrm{O}(\mathrm{V}- \\
\mathrm{PDB}, \% 0)\end{array}$ & $\begin{array}{l}\mathrm{T}{ }^{\circ} \mathrm{C}(\mathrm{Kim} \text { and } \\
\text { O'Niel, 1997) }\end{array}$ & $\begin{array}{l}\mathrm{T}^{\circ} \mathrm{C} \text { (Coplen, } \\
2007)\end{array}$ & $\begin{array}{l}\mathrm{T}{ }^{\circ} \mathrm{C} \text { (Kele et al., } \\
2015 \text { ) }\end{array}$ & $\begin{array}{l}\text { Origin of } \mathrm{CO}_{2} \text { (Panichi and } \\
\text { Tongiorgi, 1976) }\end{array}$ & $\begin{array}{l}\text { Origin of } \mathrm{CO}_{2} \\
\text { (Bottinga, 1968) }\end{array}$ \\
\hline $\begin{array}{l}\text { SU } 13 \text { ATO } \\
02 \mathrm{~m}\end{array}$ & Massive tr. & -0.50 & -11.47 & 243 & 33.2 & 38.1 & -11.10 & -9.18 \\
\hline $\begin{array}{l}\text { SU } 13 \text { ATO } \\
03 \mathrm{~m}\end{array}$ & $\begin{array}{l}\text { Wavy } \\
\text { laminated tr. }\end{array}$ & 0.29 & -10.86 & 21,3 & 29.9 & 35.2 & -10.15 & -9.18 \\
\hline $\begin{array}{l}\text { SU } 13 \text { ATO } 10 \\
\mathrm{mI}\end{array}$ & Massive tr. & 0.02 & -12.03 & 27.1 & 36.3 & 40.9 & -10.48 & -9.18 \\
\hline $\begin{array}{c}\text { SU } 13 \text { ATO } \\
12 \mathrm{~m}\end{array}$ & Massive tr. & -0.20 & -11.75 & 25.7 & 34.7 & 39.5 & -10.74 & -9.18 \\
\hline $\begin{array}{l}\text { SU } 13 \text { ATO } \\
14 \mathrm{~m}\end{array}$ & Massive tr. & -0.03 & -10.41 & 19.1 & 27.5 & 33.0 & -10.54 & -9.18 \\
\hline $\begin{array}{l}\text { SU } 13 \text { ATO } \\
15 \mathrm{~m}\end{array}$ & Massive tr. & 0.06 & -11.97 & 26.8 & 35.9 & 40.6 & -10.42 & -9.18 \\
\hline $\begin{array}{l}\text { SU } 13 \text { ATO } \\
16 \mathrm{~m}\end{array}$ & $\begin{array}{l}\text { Phytohermal } \\
\text { tr. }\end{array}$ & -0.03 & -11.63 & 25.1 & 34.1 & 38.9 & -10.54 & -9.18 \\
\hline $\begin{array}{l}\text { SU } 13 \text { ATO } \\
17 \mathrm{~m}\end{array}$ & $\begin{array}{l}\text { Phytohermal } \\
\text { tr. }\end{array}$ & 0.44 & -10.81 & 21.0 & 29.6 & 34.9 & -9.97 & -9.18 \\
\hline $\begin{array}{c}\text { SU } 13 \text { ATO } \\
18 \mathrm{~m} \mathrm{I}\end{array}$ & $\begin{array}{l}\text { Phytohermal } \\
\text { tr. }\end{array}$ & 0.26 & -11.44 & 24.1 & 33.0 & 37.9 & -10.19 & -9.18 \\
\hline $\begin{array}{l}\text { SU } 13 \text { ATO } \\
19 \mathrm{~m}\end{array}$ & $\begin{array}{l}\text { Wavy } \\
\text { laminated tr. }\end{array}$ & 0.18 & -12.41 & 29.0 & 38.4 & 42.8 & -10.29 & -9.18 \\
\hline $\begin{array}{l}\text { SU } 13 \text { ATO } \\
20 \mathrm{~m}\end{array}$ & $\begin{array}{l}\text { Phytohermal } \\
\text { tr. }\end{array}$ & -0.27 & -11.20 & 23.0 & 31.7 & 36.8 & -10.82 & -9.18 \\
\hline $\begin{array}{c}\text { SU } 13 \text { ATO } \\
21 \mathrm{~m}\end{array}$ & Massive tr. & 0.13 & -11.37 & 23.8 & 32.6 & 37.6 & -10.34 & -9.18 \\
\hline $\begin{array}{l}\text { SU } 13 \text { ATO } 23 \\
\text { mI }\end{array}$ & $\begin{array}{l}\text { Flat laminated } \\
\text { tr. }\end{array}$ & 0.07 & -12.08 & 27.4 & 36.6 & 41.1 & -10.41 & -9.18 \\
\hline $\begin{array}{c}\text { SU } 13 \text { ATO } \\
24 \mathrm{~m}\end{array}$ & $\begin{array}{l}\text { Phytohermal } \\
\text { tr. }\end{array}$ & -2.21 & -12.44 & 29.2 & 38.6 & 42.9 & -13.15 & -9.18 \\
\hline $\begin{array}{l}\text { SU } 13 \text { ATO } 10 \\
\text { mII }\end{array}$ & Massive tr. & -1.54 & -10.97 & 21.8 & 30.5 & 35.7 & -12.35 & -10.21 \\
\hline $\begin{array}{c}\text { SU } 13 \text { ATO } \\
18 \mathrm{~m} \mathrm{II}\end{array}$ & $\begin{array}{l}\text { Phytohermal } \\
\text { tr. }\end{array}$ & 0.11 & -11.91 & 264 & 35.6 & 40.2 & -10.37 & -10.21 \\
\hline $\begin{array}{c}\text { SU } 13 \text { ATO } \\
23 \mathrm{~m} \mathrm{II}\end{array}$ & $\begin{array}{l}\text { Flat laminated } \\
\text { tr. }\end{array}$ & -1.39 & -11.16 & 22.7 & 31.5 & 36.6 & -12.16 & -9.18 \\
\hline $\begin{array}{l}\text { SU } 13 \text { ATO } 02 \\
\text { c }\end{array}$ & Massive tr. & 0.70 & -11.96 & 26.7 & 35.9 & 40.5 & -9.67 & -9.18 \\
\hline $\begin{array}{l}\text { SU } 13 \text { ATO } 14 \\
\text { c }\end{array}$ & Massive tr. & -0.12 & -10.71 & 20.5 & 29.1 & 34.4 & $-10 ., 65$ & -9.18 \\
\hline$\underset{c}{\text { SU }} 13$ ATO 18 & $\begin{array}{l}\text { Phytohermal } \\
\text { tr. }\end{array}$ & 0.25 & -12.30 & 28.5 & 37.8 & 42.2 & -10.20 & -10.21 \\
\hline$\underset{\mathrm{c}}{\text { SU }} 13$ ATO 20 & $\begin{array}{l}\text { Phytohermal } \\
\text { tr. }\end{array}$ & -1.18 & -13.14 & 32.8 & 42.6 & 46.5 & -11.92 & -10.21 \\
\hline$\underset{\mathrm{c}}{\text { SU }} 13$ ATO 21 & Massive tr. & -0.13 & -11.05 & 22.2 & 30.9 & 36.1 & -10.65 & -9.18 \\
\hline $\begin{array}{c}\text { SU } 13 \text { ATO } \\
17 \mathrm{C} \mathrm{I}\end{array}$ & $\begin{array}{l}\text { Phytohermal } \\
\text { tr. }\end{array}$ & -1.67 & -12.10 & 27.4 & 36.7 & 41.2 & -12.50 & -9.18 \\
\hline $\begin{array}{l}\text { SU } 13 \text { ATO } 17 \\
\text { c II }\end{array}$ & $\begin{array}{l}\text { Phytohermal } \\
\text { tr. }\end{array}$ & -3.38 & -10.98 & 21.8 & 30.5 & 35.7 & -14.55 & -9.18 \\
\hline Mean values & & -0.2 & -11.59 & 24.9 & 33.9 & 38.7 & -11.01 & -9.35 \\
\hline
\end{tabular}

is taking place. After a while the surrounding water film becomes oversaturated with respect to calcite resulting in carbonate precipitation around the roots (Wright and Tucker, 1991). In the Gazda travertine, the formation of sparite was interrupted by the activity of endolithic microbes and fungi, boring into the already precipitated calcite crystals. This mechanism could have resulted in thin micrite envelops and micrite clouds along calcite spar horizons. The combination of these features denote a marshy (palustrine) environment colonized by plants and subject to at least ephemeral pedogenesis.

Oncoids were also observed together with calcimicrobes (Fig. 7F and G). According to Wright and Tucker (1991) oncoids can be interpreted as biologically-coated grains and regularly form along the margins of shallow ponds. Wave action on or near the shore is also important in the course of their formation (Pentecost, 2005). On the basis of morphological characteristics, the observed bushlike calcimicrobes may correspond to the cyanobacterium Rivularia haematites, a typical microbe in recent shallow freshwater environments (Portman et al., 2005). In several cases, broken pieces of calcimicrobe bushes regularly provide nuclei for the formation of oncoids. Within the shallow pond, water movement could cause fragmentation of microbial "bushes". Under these conditions several types of clasts (redeposited micrite clasts, gastropod and ostracod shell fragments as well as phytoclasts) could give rise to oncoids with variegated cores, sizes and shapes. The latter were washed into the pond where they became embedded in the dense micritic matrix. The change between calm and agitated environments was repeated several times as reflected by the alternation of oncoidal units with dense micrite, the latter being characterized by microbial bushes.

\subsection{Diagenesis}

Since the Süttő travertine complex is young and it is overlain only by a few to tens of meters of the Pleistocene loess, the effects of burial diagenesis can be excluded. The most significant impact on 


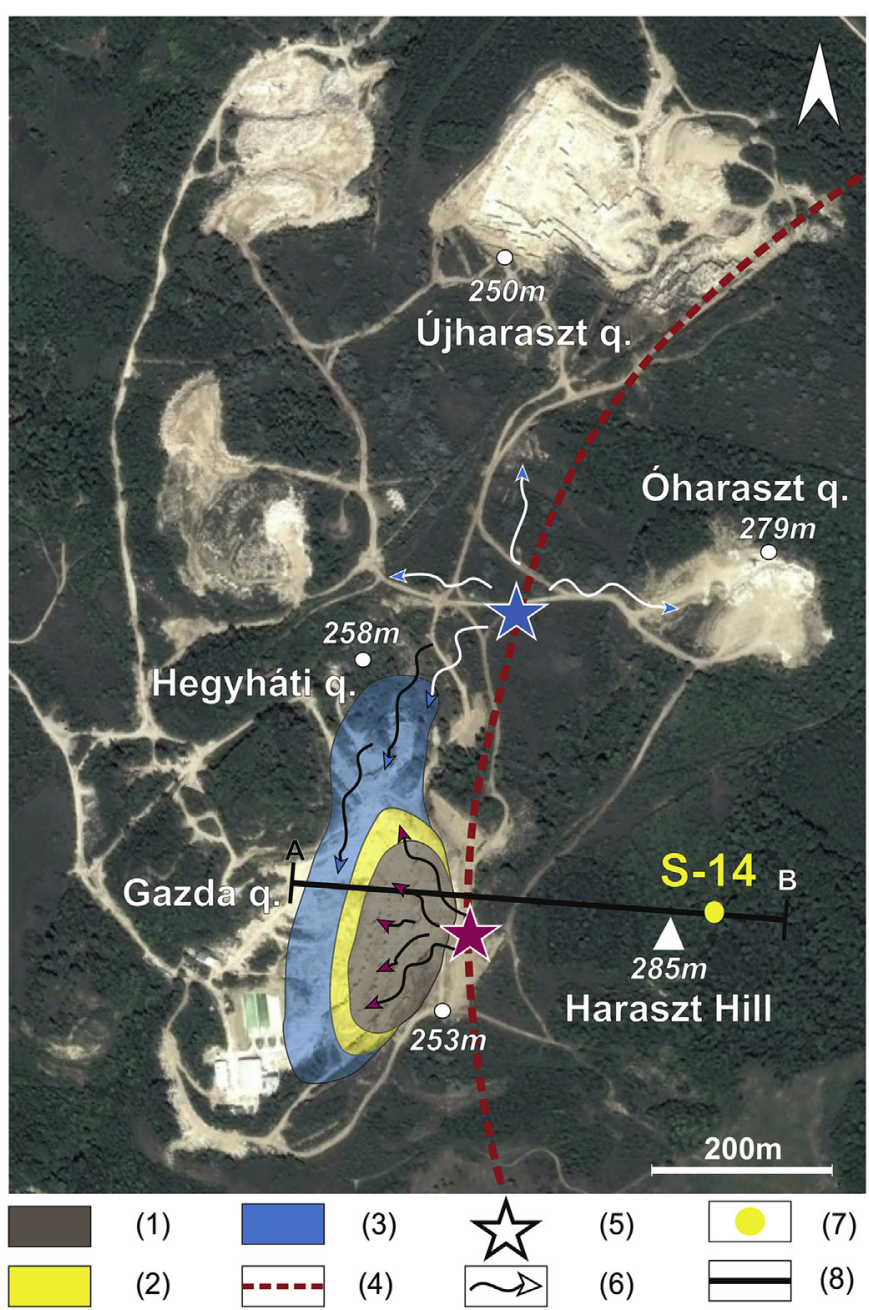

Fig. 14. Modified Google Earth image of the Süttö travertine complex with indication of topographic elevations and spatial distribution of the observed lithofacies within Hegyhát-Gazda travertine system (Google Earth). White dots indicate the given elevation of the quarries. Legend: 1: Phytohermal travertine 2: Wavy laminated travertine, 3: Massive travertine, 4: Supposed fault, 5: Discharge point(s), 6: Flow-pathway of spring water, 7: Borehole, 8: Cross-section.

the original texture of the studied continental carbonates relates to meteoric syn-diagenesis that took place under essentially the same conditions as precipitation and the formation of the primary fabrics.

Cementation is the most important diagenetic process. The precipitation of early framework stabilizing sparite is noteworthy. In the case of phytohermal travertine, elongated, fan-shaped crystals, and sparites formed around the living plants in the course of sedimentation. These cement generations can be regarded as primary fabrics (Fig. 8A). The primary pores of the Gazda travertine are significantly reduced by several cement phases that can be interpreted as secondary fabrics precipitated from spring-water percolating through the open porosity of the already lithified framework of the travertine. These calcite crystals are void-filling like equant subhedral macrosparite and bladed calcite cement within the pores (e.g. Fig. 8D and G). The high degree of cementation reflects the high saturation degree of the water and high flow-rate too.

Neomorphism is also an often observed phenomenon in the Gazda travertine. Under optical microscopy, anhedral mosaic cement was observed in which randomly distributed micrite clouds were present as ghost structures (Fig. 8H and I). According to some authors such fabrics may be the results of aggradational neomorphism (Love and Chafetz, 1988) or post-depositional growth (Brasier et al., 2011). Another possible origin of the micritic ghost textures may be sparmicritization, similar to the one reported by Guo and Riding (1994) from the shrubs of Rapolano Terme.

Another type of recrystallization was observed in solid inclusion rich calcite crystals with irregular crystal edges. Their recrystallization is shown by their mottled bright luminescent fabric (Fig. 8B, C, E, F). They likely reflect aggrading neomorphism during which the original primary fabric, probably consisting of clotted micrite, was apparently not preserved. It remains to be understood whether the solid inclusions are perhaps the remnants of the non-carbonate phases of the recrystallized primary micrite.

Dissolution phenomena were detected mainly in fracture zones and along Marker horizons. Calcite crystals with rounded edges were also observed within pores that could have been formed on contact with locally undersaturated pore fluid. The undersaturation could be caused by decomposition of organic matter or increased influx of rain water. The most obvious evidence for diagenetic overprinting is associated with the already mentioned Marker horizons along which significant dissolution occurred. A few decimetres (ca. $30-50 \mathrm{~cm}$ ) below these horizons secondary carbonate accumulations were also observed (Fig. 5).

\subsection{Origin and evolution of deformation features}

With regard to the origin of the fractures, the question whether they were formed by tectonic forces or due to gravitationally controlled slope movements can be raised. The latter is at least as probable as the involvement of real tectonic forces, because the area is topographically dissected, and the immediate substratum of the travertine consists of fine clastics particularly prone to gravity sliding.

Both reverse and normal faults have a similar strike, with reverse faults often being steeper. Sediment infill is often associated with reverse faults indicating a sub-vertical extension. The latter suggests that the footwall block could have been subject to gravitational sliding.

Sediment-filled fractures and some small-displacement faults are often perpendicular to the inclined sedimentary beds. This may indicate that the strain (stress) axes are parallel to bedding. Since these sedimentary units (mostly the wavy laminated lithofacies) have a depositional dip of $10-15^{\circ}$, a gravitational force can be invoked for the origin of the fractures.

The fractures have width from 0.2 up to $7 \mathrm{~m}$. In the wide fractures only minor shear displacement occurred along the fracture wall, and only joints and small-displacement faults affected the infill (Fig. 10). These observations show that the opening of the fractures preceded sedimentation of the infill because gradual opening of the fracture would have induced steep and faulted beds at the bottom and less steep dips upward, however, such sediment geometries were not observed. The large fracture width seems to exclude slow creeping as an opening mechanism, because in this case steeply dipping sediment packages would have been preserved in the infill. A large single earthquake is also unlikely as the cause of the sudden fracture opening. Most probably, a gravity sliding event, having resulted in fast deformation, could have been responsible for the opening of wide fractures (and possibly also for the others).

Faults related to domino blocs generally are connected to gently dipping or sub-horizontal detachment surfaces (Wernicke and Burchfiel, 1982). In the case of the domino faults observed near the entrance of the quarry the detachment surface might have been either the Quaternary gravelly clay or - slightly below that - the Pannonian fine clastics (Figs. 11 and 13). In both cases, displacement along a surface close to the base of the travertine unit is quite 


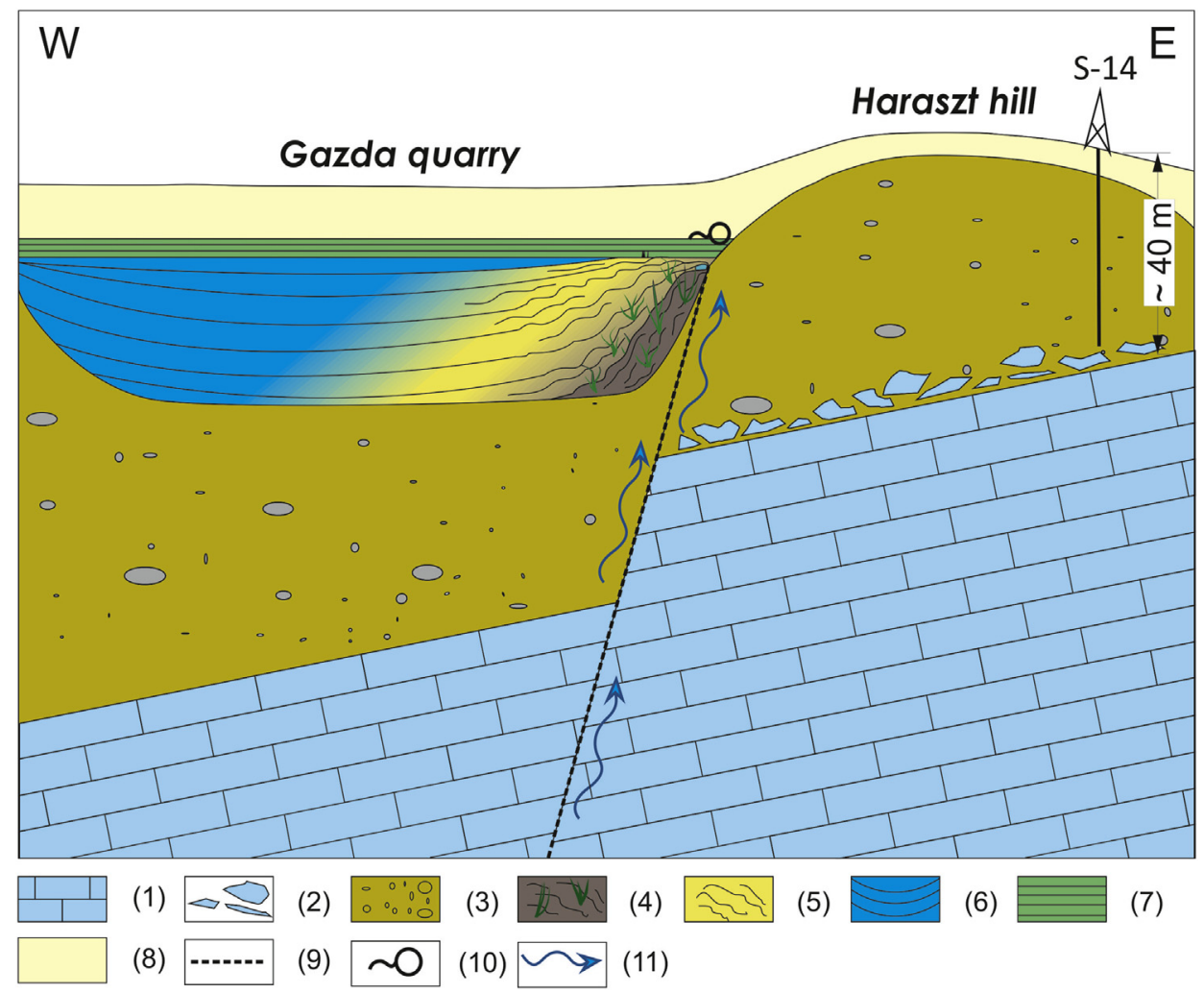

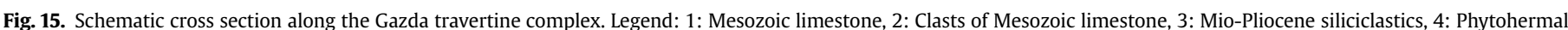

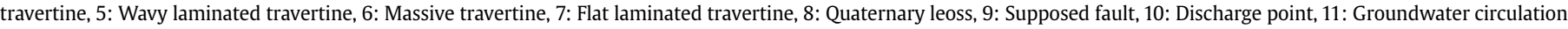
pathway.

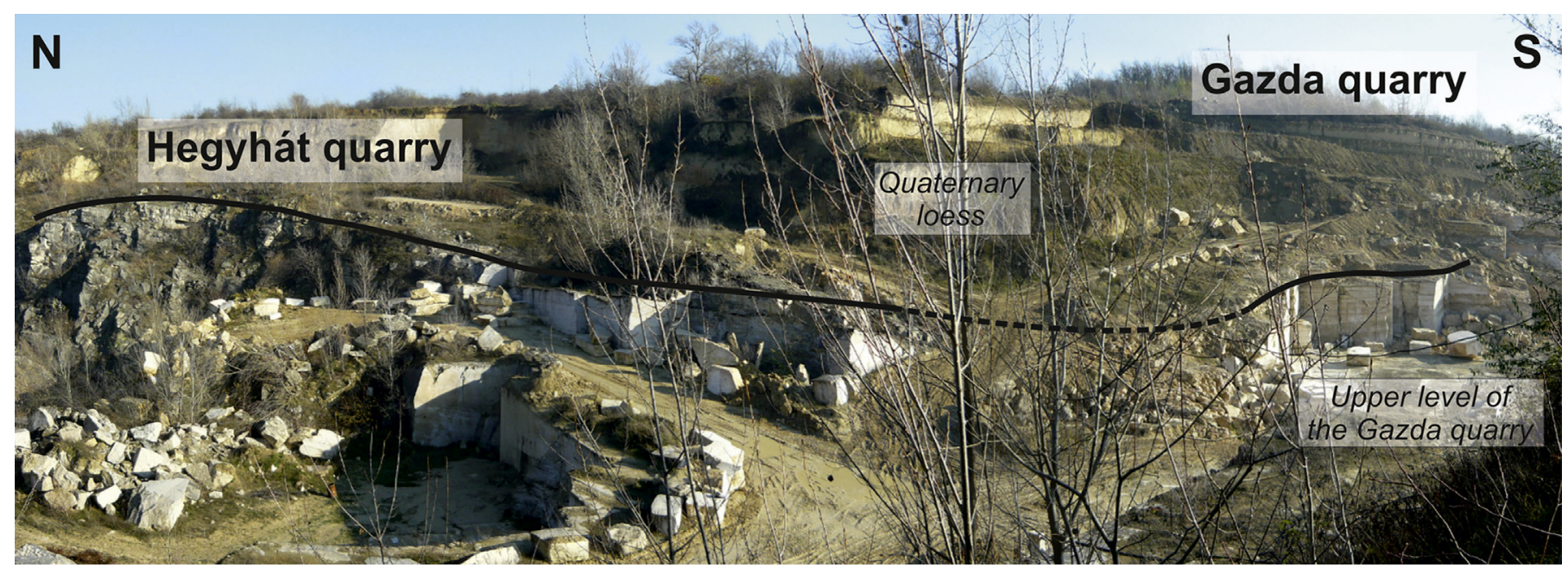

Fig. 16. Continuous travertine beds on the boundary of Gazda and Hegyhát quarries. The black line indicates the general synform.

possible. Fault orientation in this domino system points to a weak basal slip plane dipping to the SE (Fig. 11A).

To conclude, most, if not all, fractures are not related to tectonic forces, but rather to local stress related to gravitational sliding. However it cannot be excluded that true tectonic forces, namely a NW-SE tension could also have played a role in the formation of the fractures (particularly of those which are filled by calcite rather than by unconsolidated loess/sand). Present-day stress field, derived from borehole breakout data, overcoring stress determination and earthquake focal mechanisms indicate a strike-slip type stress field also with NW-SE tension (Gerner et al., 1999; Bada et al.,
2007), although this principal stress direction was not controlled by local data, but projected from surrounding areas. This means that our field observations do not allow the firm separation of tectonically and gravitationally controlled fractures although the latter is favoured.

\subsection{Stable carbon and oxygen isotopes}

\subsubsection{Carbon isotopes}

Stable carbon isotopes can provide information on the source of the $\mathrm{CO}_{2}$. Theoretically the main sources of $\mathrm{CO}_{2}$ in travertine 


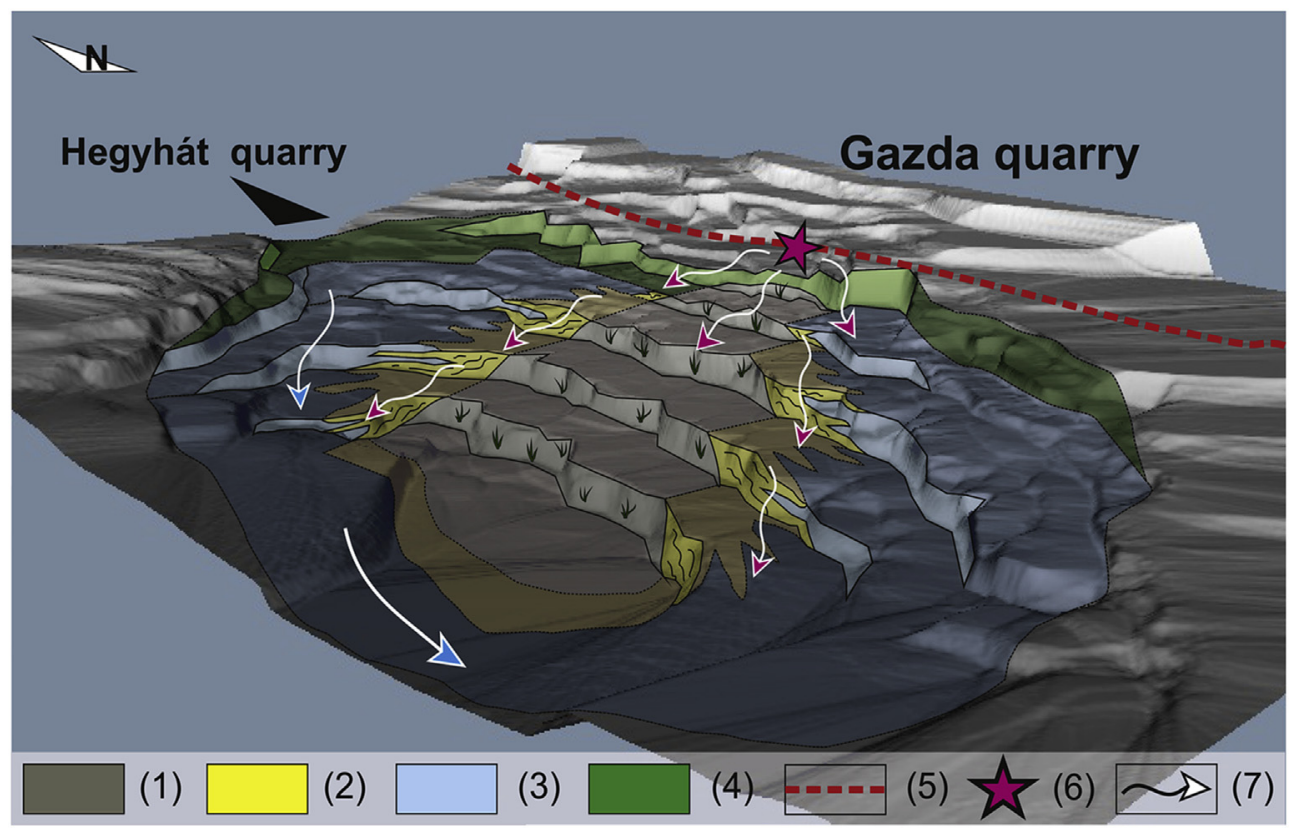

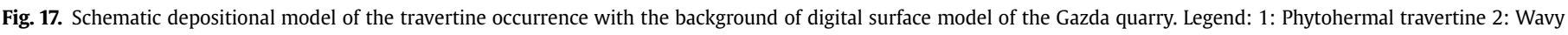
laminated travertine, 3: Massive travertine, 4: Flat laminated travertine, 5: Supposed fault, 6: Discharge point, 7: Flow-pathway of spring water

depositional environments may be marine limestones, soil related carbon (C3 and C4 plants), igneous and atmospheric carbon (Turi, 1986; Hoefs, 1997; Ghosh and Brand, 2003; Pentecost, 2005). Depending on the source of $\mathrm{CO}_{2}$, meteogene and thermogene travertines can be distinguished (Pentecost, 2005).

Using the empirical equation of Panichi and Tongiorgi (1976) the $\delta^{13} \mathrm{C}_{\mathrm{CO} 2}$ of the precipitation waters was calculated. $\delta^{13} \mathrm{C}_{\mathrm{CO} 2}$ values range between $-13.15 \%$ and $-9.97 \%$ (mean value: $-11.01 \%$ \pm 1.17 ). The $\delta^{13} \mathrm{C}_{\mathrm{CO} 2}$ was also calculated by the theoretical equation of Bottinga (1968), resulting in similar $\delta^{13} \mathrm{C}_{\mathrm{CO} 2}$ values that are varying between $-10.21 \%$ and $-9.18 \%$ (mean value: $-9.35 \%$ \pm 0.39 ). However, several factors (e.g. downstream $\mathrm{CO}_{2}$ degassing; Kele et al., 2011) can modify the original $\delta^{13} \mathrm{C}_{\mathrm{CO} 2}$ signature of the fluid, therefore the calculated $\delta^{13} \mathrm{C}$ value is not necessarily representative of the original carbon isotopic signature of the fluid from which the carbonate mineral precipitated.

Beneath the Süttö travertine complex, the most plausible carbon sources (i.e. primary carbonates) are the Triassic and Jurassic carbonate sequences that are situated ca. $50 \mathrm{~m}$ below the travertine deposits and they made up also the bulk of the regional aquifer. During its long underground circulation, the infiltrated meteoric water could have dissolved these carbonate rocks, becoming enriched in dissolved carbonate of marine limestone origin. Based on the relatively low values of calculated $\delta^{13} \mathrm{C}_{\mathrm{CO} 2}$ (with mean calculated $\delta^{13} C_{\mathrm{CO} 2}$ value: $\left.-11.01 \% \pm 1.17\right)$, it is suggested that the carbon source of the Süttö travertine results from a mixture of (a) soil derived $\mathrm{CO}_{2}$, possibly picked up on infiltration, (b) atmospheric $\mathrm{CO}_{2}$, incorporated in the water either on infiltration or at the site of deposition and (c) rock-derived $\mathrm{CO}_{3}$ and $\mathrm{HCO}_{3}^{-}$produced on dissolution of rocks of the Mesozoic reservoir. Sierralta et al. (2010) also carried out stable isotope measurements on samples from the neighbouring quarries. Based on their calculated $\delta^{13} \mathrm{C}_{\mathrm{CO} 2}$ signature they suggested a similar mixture for the process of travertine formation. The mixing origin based on the $\delta^{13} \mathrm{C}_{\mathrm{CO} 2}$ is in accordance with the measured $\delta^{13} \mathrm{C}$ values of the Süttö samples that fall within the overlapping area of meteogene and thermogene travertines.

Finally the carbon isotopic composition of the facies and their specific location in the quarry shows no unequivocal trends.
Therefore, the variation in carbon isotope values can be interpreted partly as variation in the amount $\mathrm{CO}_{2}$ derived from the different proposed sources, partly by the various types of degassing processes (biological or abiological). As the $\delta^{13} \mathrm{C}$ values of the micrite and the cement phases display similar values (Fig. 18), they likely formed from the same fluid.

\subsubsection{Oxygen isotopes}

The temperature of the travertine depositing fluid can be calculated using the conventional oxygen isotope thermometer of McCrea (1950), which is based on the temperature dependence of the calcite-water oxygen isotope fractionation using both the $\delta^{18} \mathrm{O}$ values of the travertines and of the precipitating water. However, this approach assumes equilibrium fractionation during travertine formation, which is not necessarily true in all travertine depositional environments (see Kele et al., 2008, 2011) and for the calculation of the 'closest-to-equilibrium' temperature, samples preferentially from vent and pool facies should be used (Yan et al., 2012; Kele et al., 2015). Besides, for temperature calculation the $\delta^{18} \mathrm{O}_{\text {SMOW }}$ of palaeowaters has to be estimated, introducing further uncertainty into the calculated temperatures.

In Table 2 the calculated temperature data for both matrix and cement phases are given. For the calculations, the $\delta^{18} \mathrm{O}_{\text {water }}$ was estimated based on the water isotope interpolation map of Bowen and Revenaugh (2003) and modern precipitation was taken into account $\left(\delta^{18} \mathrm{OW}=-8.1 \%\right.$ V-SMOW $)$, an approach in line with Sierralta et al. (2010). For temperature calculation the equations of Kim and O'Neil (1997), and empirical equations of Coplen (2007) and Kele et al. (2015) were used. According to the equation of Kim and O'Neil (1997), the calculated temperatures of micrite phases ranges between 19.1 and $29{ }^{\circ} \mathrm{C}$ (mean value: $24.5^{\circ} \mathrm{C} \pm 2.9$ ) whereas the temperatures of cement phases fall between 20.5 and $32.8{ }^{\circ} \mathrm{C}$ (mean value: $25.7{ }^{\circ} \mathrm{C} \pm 3.6$ ). However, when using the equation of Coplen (2007), the resulting temperature values are significantly higher (Table 2) with values varying around $33.5{ }^{\circ} \mathrm{C}$ $( \pm 3.16)$ for micrite and mean cement values of $34.8^{\circ} \mathrm{C}( \pm 4.9)$. Similar high values are derived when using the empirical equation of Kele et al. (2015) with temperatures varying around $38.4{ }^{\circ} \mathrm{C}$ 


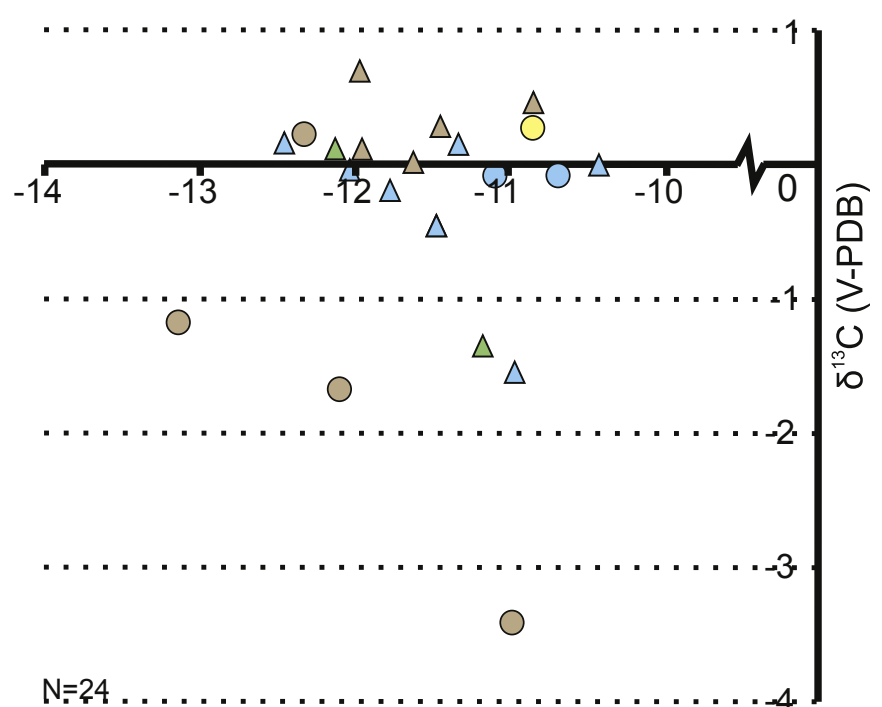

$\delta^{18} \mathrm{O}(\mathrm{V}-\mathrm{PDB})$

Phytohermal travertine

Wavy laminated travertine

Flat laminated travertine

Massive travertine

$\triangle$ Micrite

Fig. 18. Cross-plot of $\delta^{13} \mathrm{C}-\delta^{18} \mathrm{O}$ values of the identified lithofacies.

( \pm 2.82$)$ for the micrites and $39.5^{\circ} \mathrm{C}( \pm 4.32)$ for the cements.

Our calculations demonstrate that the derived temperatures strongly depend on which equation is used in the calculations. Although the most widely used equation is the one of Kim and O'Neil (1997), it is based on experimental studies performed in laboratory. The empirical equation (i.e. the new fractionation factor) of Coplen (2007) might also be a good approach as it is based on empirical observations, however, this equation is based on only one sample dataset and its slope is extrapolated from the Kim and O'Neil (1997) calibration. The empirical calibration of Kele et al. (2015) has a slightly steeper slope (i.e. higher temperature sensitivity) and it includes several sampling points from vent and pool environments. It is assumed to represent close to equilibrium conditions at naturally forming travertine sites. It is, however, unclear if the calculated temperatures (for downstream samples) may show significant deviations from equilibrium temperatures (Kele et al., 2011).

An alternative interpretation relates to the diagenetic resetting of the stable oxygen signature. Based on the petrographic investigation, recrystallization has been commonly detected which may have had some impact on the original stable oxygen isotope signature. However, recrystallization is clearly a syn-depositional process that could take place under similar conditions as precipitation of the primary fabrics, an assumption supported by the stable oxygen isotope values of micritic and sparite phases that do not differ significantly. Therefore the isotope signatures will likely still reflect fractionation from the original waters.

Additional information can be deduced from the phytohermal travertine. They show that the environment in the course of carbonate precipitation was suitable for colonization by hydrophilic plants. These plants can therefore be used as environmental indicators. Some species of these hydrophilic plants can tolerate $15^{\circ} \mathrm{C}$ whereas the optimum temperature of some other species is 30-35 ${ }^{\circ} \mathrm{C}$ (Dilks and Protcor, 1975). However, Glime and Vitt (1984) reported that some aquatic bryophytes have a wider range of optimum temperature than terrestrial bryophytes. Based on the phytohermal travertines, the equation of Kim and O'Niel (1997) provides the most plausible temperature values for carbonate precipitation in case of the Gazda quarry.

\section{6.. Conclusions}

The depositional environment of the Pleistocene travertine occurrence of the Gazda quarry has been reconstructed. Based on an integrated sedimentological, petrographic, structural geological and geochemical approach, the following major conclusions can be put forward:

(1) Based on macroscopic observations phytohermal, wavy laminated, massive and flat laminated travertine lithofacies were identified that represent reed mound, slope, lacustrine and palustrine depositional environments. The borehole logs indicate that there is probably a fault in-between the Gazda travertine and the Haraszt Hill. This supposed fault could have provided the pathways for uprising waters. Facies distribution and the geometry of the travertine bodies suggest that one of the groundwater discharge points wassituated to the east of Gazda quarry and another discharge point inbetween the Óharaszt and Hegyhát quarries. The general layout of the Gazda-Hegyhát travertine shows that the waterflow followed the course of a NE-SW striking valley. In the Gazda quarry, a topographic irregularity is supposed close to the discharge point that became colonized by hydrophilic plants and an incipient mound began to grow there. After passing over the mound, further down the overflowing water could have encountered another topographic "obstacle" to the SSW causing the establishment of a subsequent pond environment in between these two obstacles. The onlapping flat laminated travertine suggests that this laminated travertine could have been deposited from waters originating in the eastern part of the pond-slopemound system and became interfingered with the other pond facies.

(2) Microscopic observations show that the primary fabric is mainly represented by dense, clotted micrite and clumps of clotted micrite that likely formed to some extent by microbial mediation. In addition, micrite coatings and micritesparite crusts around primary fabrics and intraclasts may represent an early stage of micritization. Primary pores are significantly reduced by several cement phases.

(3) Structural geological observations suggest that most fractures were related to gravitational sliding. However, it cannot be excluded that true neotectonic forces resulting in NW-SE tension also played a role in the formation of the fractures. Much of the deformation having affected the travertine is related to the partly syn-sedimentary landscape-lowering denudation event. All these deformations reflect that gravitational instability has influenced the deformation of the travertine body at least until Late Pleistocene times.

(4) Stable oxygen and carbon isotope analyses show that temperature of the travertine precipitating waters was approximately $25^{\circ} \mathrm{C}$ (range between 20.5 and $32.8^{\circ} \mathrm{C}$ ). The original stable oxygen isotope signatures were preserved and show that the Gazda travertine was deposited from lukewarm meteoric waters of slightly modified composition. Based on the relatively low values of the calculated $\delta^{13} \mathrm{C}_{\mathrm{CO} 2}$, the carbon dioxide source was a mixture of predominantly atmospheric and soil derived $\mathrm{CO}_{2}$, likely modified by rock-water interaction in the karstic reservoir. 


\section{Acknowledgements}

The authors are grateful to T. Adamcsik (Reneszánsz Ltd.) and his colleagues for their help in the course of the field work. H. Nijs (KU Leuven, Belgium) is thanked for thin section preparation and Prof. M. Joachimski for helping with the oxygen and carbon stable isotope measurements. O. Györi and M. Marques Erthal are also thanked for scientific discussions as well as I. Kudó (Geomega Ltd., Hungary) and G. Surányi (Eötvös L. University, Hungary) for digital mapping of the Gazda quarry. The authors are also grateful to TOTAL, BG and PETROBRAS for funding this project. S. Kele received support by the János Bolyai research scholarship of the Hungarian Academy of Sciences. This study was partly supported by the Hungarian National Research Fund (OTKA 101664).

\section{References}

Anderson, E.M., 1951. The Dynamics of Faulting and Dyke Formation with Application to Britain. Oliver and Boyd, Edinburgh.

Alonso-Zarza, A.M., Tanner, L.H., 2010. Carbonates in Continental Settings. Elsevier, Amsterdam.

Alonso-Zarza, A.M., Wright, P., 2010. Palustrine carbonates. In: Alonso-Zarza, A.M., Tanner, L.H. (Eds.), Carbonates in Continental Settings. Elsevier, Amsterdam, pp. 103-131.

Angelier, J., 1984. Tectonic analysis of fault slip data sets. J. Geophys. Res. 89, $5835-5848$

Arenas, C., Casanova, J., Pardo, G., 1997. Stable isotope characterization of the Miocene lacustrine systems of Los Monegros (Ebro Basin, Spain): palaeogeographic and palaeoclimatic implications. Palaeogeogr. Palaeoclimatol. Palaeoecol. 128, 133-155.

Bada, G., 1999. Cenozoic Stress Field Evolution in the Pannonian Basin and Surrounding Orogens: Inferences from Kinematic Indicators and Finite Element Modelling. Ph.D. Thesis. Vrije University Amsterdam.

Bada, G., Grenerczy, Gy, Tóth, L., Horváth, F., Stein, S., Cloetingh, S., Windhoffer, G. Fodor, L., Pinter, N., Fejes, I., 2007. Motion of Adria and ongoing inversion of the Pannonian basin: seismicity, GPS velocities and stress transfer. In: Stein, S. Mazzotti, S. (Eds.), Continental Intraplate Earthquakes: Science, Hazard, and Policy Issues. Geological Society of America Special Paper 425.

Bakacsi, Zs, Mindszenty, A., 2004. Pleistocene Travertine Deposits of Süttő (Gerecse Hills, Hungary). Excursion Guide, Climate and Tectonic Controls on Travertine Formation: the Case of the Pannonian Basin. Field Course, Tata, Egerszalók pp. 13-20.

Bottinga, Y., 1968. Calculation of fractionation factor for carbon and oxygen isotopic exchange in the system calcite-carbon dioxide-water. J. Phys. Chem. 72, $800-808$.

Bowen, G.J., Revenaugh, J., 2003. Interpolating the isotopic composition of modern meteoric precipitation. Water Resour. Res. 39, 1299.

Brasier, A.T., Andrews, J.E., Kendall, A.C., 2011. Diagenesis or dire genesis? The origin of columnar spar in tufa stromatolites of Central Greece and the role of chironomid larvae. Sedimentology 58, 1283-1302.

Capezzuoli, E., Gandin, A., Pedley, M., 2014. Decoding tufa and travertine (fresh water carbonates) in the sedimentary record: the state of the art. Sedimentology $61,1-21$.

Chafetz, H.S., Folk, R.L., 1984. Travertines: depositional morphology and the bacterially-constructed constituents. J. Sediment. Petrology 54, 289-316.

Choquette, P.W., Pray, L.C., 1970. Geologic nomenclature and classification of porosity in sedimentary carbonates. AAPG Bull. 54/2, 207-250.

Claes, H., Soete, J., Van Noten, K., El Desouky, H., Erthal, M.M., Vanhaecke, F. Özkul, M., Swennen, R., 2015. Sedimentology, three-dimensional geobody reconstruction and carbon dioxide origin of Pleistocene travertine deposits in the Ballık area (south-west Turkey). Sedimentology 62 (5), 1408-1445.

Claes, H., Degros, M., Soete, J., Claes, S., Kele, S., Mindszenty, A., Török, Á, El Desouky, H., Vanhaecke, G., Swennen, R., 2016. Geobody architecture, genesis and petrophysical characteristics of the Budakalász travertines, Buda Hills (Hungary). Quat. Int. Special Volume (in press).

Coplen, T.B., 2007. Calibration of the calcite-water oxygen-isotope geothermometer at Devils Hole, Nevada, a natural laboratory. Geochimica Cosmochimica Acta 71 (No. 16), 3948-3957.

D'Argenio, B., Ferreri, V., 1987. A brief outline of sedimentary models for Pleistocene travertine accumulation in Southern Italy. Rend. Soc. Geol. It 9, 167-170.

Dilks, T.J.K., Proctor, M.C.F., 1975. Comporative experiments on temperature responses of bryophytes assimilation, respiration and freezing damage. J. Briology 8, 317-336.

Dövényi, P. Horváth, F. 1988. A review of temperature, thermal conductivity and heat flow data from the Pannonian Basin. The Pannonian Basin. AAPG Mem. 45 195-233.

Dövényi, P., Horváth, F., Drahos, D., 2002. Geothermal thermic map (Hungary). In: Hurter, S., Haenel, R. (Eds.), Atlas of Geothermal Resources in Europe, Luxembourg.

Dunham, R.J., 1962. Classification of carbonate rocks according to depositional texture. In: Ham, W.E. (Ed.), Classification of Carbonate Rocks. AAPG Memoir, Tulsa, Oklahoma, pp. 108-120.

Fodor, L,, Csontos, L., Bada, G., Györfi, I., Benkovics, L., 1999. Tertiary tectonic evolution of the Pannonian basin system and neighboring orogens: a new synthesis of paleostress data. In: Durand, B., Jolivet, L., Horváth, F., Séranne, M. (Eds.), The Mediterranean Basins: Tertiary Extension within the Alpine Orogen. Geological Society, London, pp. 295-334.

Fodor, L., Sztanó, O., Kövér, Sz, 2013. Pre-conference field trip: Mesozoic deformation of the northern Transdanubian Range (Gerecse and Vértes Hills). Acta Miner. Petrogr. Field Guide Ser. 31, 1-34.

Folk, R.L., 1959. Practical Petrographic Classification of Limestones, vol. 43. AAPG Bulletin, Tulsa, Oklahoma.

Folk, R.L., 1993. SEM imaging of bacteria and nannobacteria in carbonate sediments and rocks. J. Sediment Petrology 63, 990-1000.

Freytet, P., Plaziat, J.C., 1982. Continental Carbonate Sedimentation and Pedogenesis, Contributions to Sedimentology, vol. 12. Elsevier, Amsterdam.

Freytet, P., Verrecchia, E.P., 2002. Lacustrine and palustrine carbonate petrography: an overview. J. Paleolimnol. 27, 221-237.

Gerner, P., Bada, G., Dövényi, P., Cloething, S., Oncescu, M., Müller, B., 1999. State of recent stress in the Pannonian Basin: data and models. In: Durand, B., Jolivet, L., Horváth, F., Séranne, M. (Eds.), The Mediterranean Basins: Tertiary Extension within the Alpine Orogen, vol. 156. Geological Society Special Publications, London, pp. 269-294.

Ghosh, P., Brand, W.A., 2003. Stable isotope ratio mass spectrometry in global climate change research. Int. J. Mass Spectrom. 228, 1-33.

Gierlowski-Kordesch, E.H., 2010. Lacustrine carbonates. In: Alonso-Zarza, A.M., Tanner, L.H. (Eds.), Carbonates in Continental Settings. Elsevier, Amsterdam, pp. $1-102$.

Gierlowski-Kordesch, E.H., Gómez-Fernández, J.C., Meléndez, N., 1991. Carbonate and coal deposition in an alluvial lacustrine setting: lower Cretaceous (Weald) in the Iberian Range (east-central Spain). In: Anadón, P., Cabrera, L., Kelts, K. (Eds.), Lacustrine Facies Analysis, vol. 13. International Association of Sedimentologists Special Publication, pp. 109-125.

Given, R.K. Wilkinson, B.H. 1985. Kinetic control of morphology, composition, and mineralogy of abiotic sedimentary carbonates. J. Sediment. Petrol. 55, 109-119.

Glime, J.M., Vitt, D.H., 1984. Physiological adaptation of aquatic Musci. Lindbergia $10,41-52$

Golubic, S., Violante, C., Ferreri, V., D'Argenio, B., 1993. Algal control and early diagenesis in quaternary travertine formation (rochetta a volturno, central apennines). In: Barattolo, F. (Ed.), Studies on Fossil Algae, vol. 1. Bollettino Societá Paleontologica Italiana, pp. 231-247. Special Volume.

Gomes, P.O., Kilsdonk, B., Grow, T., Minken, J., Barragan, R., 2012. tectonic evolution of the outer high of Santos basin, southern Sao Paulo plateau, Brazil, and implications for hydrocarbon exploration. In: Gao, D. (Ed.), Tectonics and Sedimentation: Implications for Petroleum Systems AAPG Memoir, vol. 100, pp. $125-142$.

Greenhalgh, J., Wells, S., Borsato, R., Pratt, D., Martin, M., Roberson, R., Fontes, C., Obaje, W.A. 2011. A fresh look at prospectivity of the equatorial conjugate margin of Brazil and Africa. First Break 29, 67-72.

Guo, L., Riding, R., 1994. Origin and diagenesis of Quaternary travertine shrub fabric, Rapolano Terme, central Italy. Sedimentology 41, 499-520.

Guo, L., Riding, R., 1998. Hot-spring travertine facies and sequences, Late Pleistocene, Rapolano Terme, Italy. Sedimentology 45, 163-180.

Haas, J., 2001. Geology of Hungary. Eötvös University press, Budapest.

Hancock, P.L., 1985. Brittle microtectonics: principles and practice. J. Struct. Geol. 7, $437-457$.

Hoefs, J., 1997. Stable Isotope Geochemistry. Springer-Verlag, Berlin.

Horváth, F., 1993. Towards a mechanical model for the formation of the Pannonian basin. Tectonophysics 226, 333-357.

Horváth, F., 1995. Phases of compression during the evolution of the Pannonian basin and their bearing on hydrocarbon exploration. Mar. Pet. Geol. 12, 837-844.

Horváth, F., Cloetingh, S., 1996. Stress-induced late stage subsidence anomalies in the Pannonian basin. Tectonophysics 266, 287-300.

Kele, S. 2009. Study of Freshwater Limestones from the Carpathian Basin: Paleoclimatological and Sedimentological Implications. PhD Thesis. Eötvös Loránd University, Hungary, p. 176.

Kele, S., Demény, A., Siklósy, Z., Németh, T., Mária, T., Kovács, M.B., 2008. Chemical and stable isotope compositions of recent hot-water travertines and associated thermal waters, from Egerszalók, Hungary: depositional facies and nonequilibrium fractionations. Sediment. Geol. 211, 53-72.

Kele, S., Özkul, M., Gököz, A., Fórizs, I., Baykara, M.O., Alcicek, M.C., Németh, T., 2011. Stable isotope geochemical and facies study of Pamukkale travertines: new evidences of low-temperature non-equilibrium calcite-water fractionation. Sediment. Geol. 238, 191-212.

Kele, S. Breitenbach, S.F.M., Capezzuoli, E., Meckler, A.N. Ziegler, M., Millan, I.M., Kluge, T., Deák, J., Hanselmann, K., John, C.M., Yan, H., Liu, Z., Bernasconi, S.M., 2015. Temperature dependence of oxygen- and clumped isotope fractionation in carbonates: a study of travertines and tufas in the $6-95^{\circ} \mathrm{C}$ temperature range. Geochimica Cosmochimica Acta 168, 172-192.

Keller, W.D., Frederickson, A.F., 1952. Role of plants and colloidal acids in the mechanism of weathering. Am. J. Sci. 250, 594-608.

Kim, S.T., O'Neil, J.R., 1997. Equillibrium and nonequillibrium effects in synthetic carbonates. Geochimica Cosmochimica Acta 61/16, 3461-3475.

Korpás, L., 2003. Édesvízi mészkövek: új szedimentológiai modell és kronológia. 
OTKA zárójelentés, pp. 1999-2002.

Krumbein, W.E. 1979. Calcification by bacteria and algae. In: Trudinger, P.A. Swaine, D.J. (Eds.), Biogeochemical Cycling of Mineral-Forming Elements. Elsevier, Amsterdam.

Love, K.M., Chafetz, H.S., 1988. Diagenesis of laminated travertine crusts, Arbuckle Mountains, Oklahoma. J. Sediment. Petrol. 58 (No. 3), 441-445.

Mádl-Szönyi, J., Tóth, Á., 2015. Basin-scale conceptual groundwater flow model for an unconfined and confined thick carbonate region. Hydrogeol. J. 23 1359-1380.

McCrea, J.M., 1950. On the isotopic chemistry of carbonates and a paleotemperature scale. J. Chem. Phys. 18, 849-857.

Panichi, C., Tongiorgi, E., 1976. Carbon isotopic composition of $\mathrm{CO}_{2}$ from springs, fumaroles, mofettes and travertines of central and southern Italy: a preliminary prospection method of geothermal areas. In: Proceedings: 2nd United Nations Symposium on the Developemnt and Use of Geothermal Energy, San Francisco, pp. 815-825.

Pazonyi, P., 2014. Archaeological sites of the Süttő Travertine Complex (Hungary) with stratigraqphical and paleoecological implications from their faunas. Quat. Int. 326-327, 184-190.

Pazonyi, P., Kordos, L., Magyari, E., Marinova, E., Füköh, L., Venczel, M., 2014. Pleistocene vertebrate faunas of the Süttő travertine complex (Hungary). Quat. Int. 318, 50-63.

Pécsi, M., 1959. A Magyarországi Duna-völgy Kialakulása És Felszínalaktana. Akadémiai kiadó, Budapest.

Pécsi, M., Scheuer, Gy, Schweitzer, F., 1984. Plio-Pleistocene tectonic movements and the travertine horizons in the Hungarian Mountains. Stud. Geomorphol Carpato-Balcanica 19-27.

Pedley, M., 2014. The morphology and function of thrombolitic calcite precipitating biofilms: a universal model derived from freshwater mesocosm experiments. Sedimentology 61, 22-40.

Pentecost, A., Viles, H., 1994. A review and reassessment of travertine classification. Géogr. physique Quaternaire 48, 305-314.

Pentecost, A., 2005. Travertine. Springer-Verlag, Berlin.

Platt, N.H., Wright, V.P., 1991. Lacustrine carbonates. Facies models, facies distribution and hydrocarbon aspects. In: Anaddn, P., Cabrera, L., Kelts, K. (Eds.), Lacustrine Facies Analysis, vol. 13. International Association of Sedimentologists, pp. 55-72. Special Publication.

Portman, C., Andrews, J.E., Rowe, P.J., Leeder, M.R., Hoogewerff, J., 2005. Submarinespring controlled calcification and growth of large Rivularia bioherms, Late Pleistocene (MIS 5e), Gulf of Corinth, Greece. Sedimentology 52, 441-465.

Riding, R., 2000. Microbial carbonates: the geological record of calcified bacterialalgal mats and biofilms. Sedimetology 47, 179-214.

Riding, R., Tomás, S., 2006. Stromatolite reef crusts, Early Cretaceous, Spain: bacterial origin of in situ-precipitated peloid microspar? Sedimentology 53, 23-34

Rolf, C., Hambach, U., Novothny, Á., Horváth, E., Schnepp, E., 2014. Dating of a Last Glacial loess sequence by relative geomagnetic palaeointensity: a case study from the Middle Danube Basin (Süttö, Hungary). Quat. Int. 319, 99-108.
Ronchi, P., Francesco, C., 2015. Continental carbonates as hydrocarbon reservoir, an analogue case study from the travertine of Saturnia, Italy. AAPG Bull. 4, $711-734$.

Royden, L.H., Horváth, F., 1988. The Pannonian Basin - a Study in Basin Evolution. AAPG Memoir 45, Tulsa, pp. 49-55.

Ruszkiczay-Rüdiger, Zs, Fodor, L., Bada, G., Leél-Őssy, Sz, Horváth, E., Dunai, T.J. 2005. Quantification of Quaternary vertical movements in the central Pannonian Basin: a review of chronologic data along the Danube river, Hungary Tectonophysics 410, 157-172.

Saller, A., Rushton, S., Buambua, L., Inman, K., McNeil, R., Dickson, J.A.D., 2016 Presalt stratigraphy and depositional system in the Kwanza Basin, offshore Angola. AAPG Bull. 100 (No. 7), 1135-1164.

Scheuer, G., Schweitzer, F., 1988. A Gerecse És a Budai-hegység Édesvízi Mészkőösszletei. Földrajzi Tanulmányok, vol. 20. Akadémiai Kiadó, Budapest.

Scheuer, Gy, 1996. A tatai és dunaalmási hévforrások, valamint üledékképző tevékenységük vizsgálata. Hidrológiai Tájékoztató 1996, 29-32.

Scheuer, Gy, Schweitzer, F., 1985. Az édesvízi mészkőkúpok típusai és alakulati formái. Földtani Közlöny 115, 385-398.

Schréter, Z., 1951. A Budai- és Gerecse-hegység peremi édesvízi mészkő előfordulásai. Földtani Intézet Évi Jelentése 111-150, 1949-röl.

Sierallta, M., Kele, S., Melcher, F., Hambach, U., Reinders, J., Van Geldern, R., Frechen, M., 2010. Uranium-sereies dataing of travertine from Süttő: implications for reconstruction of environmental change in Hungary. Quat. Int. 222, $178-193$.

Soete, J., Kleipool, L.M., Claes, H., Claes, S., Hamaekers, H., Kele, S., Özkul, M. Foubert, A., Reijmer, J.J.G., Swennen, R., 2015. Acoustic properties in continental carbonates and their relation to porosity and pore types. Mar. Petroleum Geol. 59, 320-335.

Tucker, M.E., Wright, V.P., 1990. Carbonate Sedimentology. Blackwell, Oxford.

Turi, B., 1986. Stable isotope geochemistry of travertines. In: Fritz, P., Fontes, J.C. (Eds.), The Terrestrial Environment, B, Handbook of Environmental Isotope Geochemistry, vol. 2. Elsevier, Amsterdam.

Violante, C., Ferreri, V., D'Argenio, B., Golubic, S., 1994. Quaternary travertines at Rochetta a Volturno (Isernia, Central Italy). Facies analysis and sedimentary model of an organogenic carbonate system. In: 15th Regional Meeting of International Association of Sedimentologists, Ischia, Italy, pp. 3-23.

Wernicke, B., Burchfiel, B.C., 1982. Modes of extensional tectonics. J. Struct. Geol. 4, 105-115.

Wright, V.P., 2012. Lacustrine Carbonates in Rift Settings: the Interaction of Volcanic and Microbial Processes on Carbonate Deposition. Geological Society, London, pp. 1-20. Special Publications.

Wright, V.P., Tucker, M.E., 1991. Calcretes: an introduction. In: Wright, V.P., Tucker, M.E. (Eds.), Calcretes. IAS Reprint Series, vol. 2. Blackwell, Oxford.

Yan, H., Sun, H., Liu, Z., 2012. Equilibrium vs. kinetic fractionation of oxygen isotopes in two low-temperature travertine-depositing systems with differing hydrodynamic conditions at Baishuitai, Yunnan, SW China. Geochimica.et Cosmochim. Acta 95, 63-78. 